Tânia Franco ${ }^{1}$

Graça Druck²

Edith Seligmann-Silva ${ }^{3}$

\section{As novas relações de trabalho, o desgaste mental do trabalhador e os transtornos mentais no trabalho precarizado}

\author{
New labor relations, worker's mental exhaustion, and mental \\ disorders in precarious work
}

1 Pesquisadora do Centro de Recursos Humanos da Faculdade de Filosofia e Ciências Humanas da Universidade Federal da Bahia (CRH/FFCH/UFBA), Salvador, BA.

2 Professora Adjunta do Departamento de Sociologia da Faculdade de Filosofia e Ciências Humanas e do Programa de Pós-Graduação em Ciências Sociais da Universidade Federal da Bahia (FFCH/ UFBA); Pesquisadora do CRH/FFCH/ UFBA, Pesquisadora do CNPq. Especialista na área de Sociologia do Trabalho, Salvador, BA.

${ }^{3}$ Médica psiquiatra com especialização em Saúde Pública. Docente aposentada da Faculdade de Medicina da Universidade de São Paulo, São Paulo, SP.

Contato:

Tânia Franco

Rua Gustavo de Andrade, nº 8/1104

Campo Grande - Salvador-Bahia, Brasil CEP: 40080-020

E-mail:

franctania@gmail.com

\section{Resumo}

A perda da razão social do trabalho tem como ressonância a perda do sentido do trabalho para aqueles que o realizam. O objetivo principal deste ensaio é analisar de que forma a saúde mental é prejudicada pelas atuais contradições entre modernização e expansão da precarização social e do trabalho. Na primeira parte, procura-se entender a questão através de uma visão sócio-histórica, expondo-se a seguir indicadores internacionais e brasileiros que demonstram essa precarização. Na sequência, as autoras apresentam uma análise crítica do modo pelo qual, a partir da busca de maximização da competitividade, surgiu um modelo social que, em nome de uma excelência cujo significado conjuga perfeição e superioridade, propicia discriminação ou exclusão para todos os que de alguma forma desvelam seus limites humanos. Os paradigmas deste modelo, atualmente dominante, são examinados para identificar os impactos psíquicos, destacando os adoecimentos relacionados à violência laboral. As autoras assinalam ainda o aumento de vulnerabilidade psíquica nos contextos de pobreza. A seguir, é apresentada uma reflexão sobre o despertencimento social e o desenraizamento humano e, na parte final, são discutidas perspectivas de reverter a degradação social, do trabalho e da natureza.

Palavras-chave: relações de trabalho; organização do trabalho; saúde mental; desgaste mental; precarização.

\begin{abstract}
Loosing the social purpose of work leads individuals to perform senseless work. This paper aims at analyzing the effect of current contradictions between modernization and expansion of labor and social precariousness on mental health. It begins by investigating this issue through a social and historical viewpoint, followed by showing international and Brazilian indicators that illustrate the above mentioned precariousness. Further on, the authors analyze critically the social model generated by targeting maximum competitiveness, which on behalf of an excellence that conjugates perfection and superiority fosters discrimination or exclusion of all those who in anyway unveil their human limits. The authors examine the current dominating paradigms of this model to identify its psychological impacts, highlighting illnesses related to occupational violence. They further stress the increase of psychic vulnerability in contexts of poverty and discuss social non-belonging and human ungrounding processes. They conclude by commenting on possibilities of reverting labor, nature, and social degradation.
\end{abstract}

Keywords: work relations; work organization; mental health; mental exhaustion; precariousness. 


\section{Introdução}

Seria alentador abordar o trabalho como meio de vida e de conquista da dignidade humana. Poder divisar o alívio do esforço/sofrimento no trabalho em face dos avanços tecnológicos e do conhecimento científico na história da humanidade. Contudo, o que se constata no mundo real do trabalho é um distanciamento crescente entre práticas organizacionais e direitos sociais conquistados. É o paradoxo que encerra o trabalho contemporâneo: sua combinação com precarização social, com adoecimento dos indivíduos e destruição ambiental.

Refletir sobre o tema conduz a indagações instigantes e inevitáveis. O que é que nos aconteceu histórica e socialmente para estarmos, hoje, a pensar em três binômios: 1) Trabalho e adoecimento, não como um problema individual, mas como um problema de saúde pública que atinge os indivíduos em escala crescente; 2) Trabalho e degradação/crise ambiental, revelando padrões de produção e consumo que rompem os limites de tempo (comprometendo gerações futuras e os mecanismos reguladores dos ecossistemas) e de espaço (contaminando populações próximas e distantes, diversas espécies, destruindo a biodiversidade, a teia da vida), depredando o planeta; 3) Trabalho e precarização social, que compromete gerações, privando-as de educação e trabalho digno, gerando violência social.

Por que os avanços da ciência e tecnológicos - patrimônio humano - não têm se traduzido em emprego e inclusão de amplas parcelas da humanidade? Por que o aumento da produtividade não tem se traduzido em redução das jornadas de trabalho sem prejuízo do salário?

Apesar dos elevados patamares tecnológicos alcançados em todo o planeta, o mundo da produção continua, predominantemente, estruturado e se movendo pela acumulação de capital e lucro. Isto leva à progressiva hipotrofia e perda de uma razão social do trabalho. A lógica produtiva permanece a mesma que regia as relações capital/trabalho no século XIX, aprofundando a apropriação privada da riqueza socialmente gerada e dos elementos da natureza, consolidando o mercado como eixo da sociedade. Esta lógica limita, ou mesmo extingue, as possibilidades do trabalho se constituir um meio de desenvolver a dignidade, a solidariedade e as potencialidades do ser humano.

Sem dúvida, ocorreram avanços históricos nas sociedades urbano-industriais capitalistas que resultaram em direitos sociais marcantes durante a Era de Ouro nos EUA, entre 1940 e 1970, e durante o Estado de Bem-Estar Social nos países europeus, entre 1950 e 1970 (HOBSBAWN, 1995). No Brasil, desde a Era Vargas, com a Consolidação das Leis do Trabalho, seus desdobramentos posteriores e a Constituição de 1988. Ao longo do tempo, ocorreu inclusão social de segmentos de trabalhadores em todos estes países, em maior ou menor grau, bem como metamorfoses nas configurações das relações capital/trabalho. Mas, ao concentrarmos nossa análise no momento atual, constatamos retrocessos sociais importantes em relação às três décadas anteriores, traduzidos na crescente precarização do trabalho.

Este é um processo complexo, pois mantém a relação capital/trabalho em sua essência, ao tempo em que transmuta as suas formas de existência. Ou seja, forja mudanças epidérmicas, de superfície, através de diferenciados estatutos de trabalhadores que camuflam a relação essencial capital/trabalho, confundindo as figuras sociais básicas representativas - empregado e empregador - que norteiam a vigência e a aplicação das leis trabalhistas ${ }^{4}$. Neutraliza e anula a regulação social do trabalho (com a consequente perda de direitos conquistados pelos movimentos sociais anteriormente), naturalizando o trabalho precário, banalizando a injustiça social e a violência no trabalho (principalmente, a violência psicológica). Dissemina uma era de precarização social $^{5}$ e de trabalho socialmente desagregador, terreno fértil para o sofrimento e o adoecimento dos indivíduos, configurando o trabalho patogênico. A precarização passou a ser um atributo central do trabalho contemporâneo e das novas relações de trabalho, apresentando múltiplas faces e dimensões.

\section{Precarização social: uma questão política e multidimensional}

Desde a crise da sociedade fordista nos anos 1970 e das supostas "saídas” preconizadas pelas políticas neoliberais, a questão social vem assumindo importância central dada a expansão do desemprego, a reemergência da pobreza nos países centrais e a fragilização do trabalho, dentre outros. Desde então, as abordagens sobre a precarização socioeconômica evoluíram nas ciências sociais, particularmente na França, transitando da noção de exclusão - usada inicialmente para situa ções extremas, como o desemprego - para abranger, contemporaneamente, as diversas situações de precarização dos incluídos, imersos na insegurança e na incerteza permanentes das políticas de gestão flexível (HIRATA; PRETÉCEILLE, 2002).

\footnotetext{
${ }^{4}$ Por exemplo, o trabalhador - ex-empregado ou não - que vira cooperado ou prestador de serviços terceirizado - autônomo ou sob a forma de empresa/pessoa jurídica - perde o estatuto de assalariado do núcleo estável da empresa contratante e, consequentemente, os direitos trabalhistas básicos ou aqueles decorrentes dos acordos coletivos da categoria à qual não pertence, dado a sua forma de contrato.

${ }^{5}$ Conforme Castel (2009, 1998), Bourdieu (2001, 1998, 1997), Harvey (1992), Appay e Thébaud-Mony (1997), Antunes (2002, 1999), Antunes e Braga (2009), Druck (1999), Druck e Franco (2007), Hirata e Préteceille (2002), Franco (1997), dentre outros.
} 
A flexibilização das relações de trabalho diluiu a nítida linha de separação entre incluídos e excluídos. Através da terceirização e da desregulamentação social, produziu-se a desestabilização do mundo do trabalho que atingiu, inicialmente, os trabalhadores industriais e depois todos os assalariados, afetando, hoje, todos os que vivem do trabalho. Este processo histórico levou à redução do emprego "fordista” (ou seja, do trabalho com um corolário de direitos e proteção social, característico da Era de Ouro ou welfare state), com uma crescente fragilização dos trabalhadores estáveis e uma persistente produção de instáveis (HARVEY, 1992), configurando a vulnerabilidade de massa (CASTEL, 1998).

O apagamento dos contornos nítidos entre incluídos e excluídos é, portanto, como bem afirmam Hirata e Pretéceille (2002, p. 48):

[...] processo cujas raízes se encontravam na fragilização da posição de grupos ou de pessoas que dispunham de um emprego e de condições de vida até aquele momento consideradas satisfatórias. Daí originaram-se as análises centradas na precariedade, precarização social e precarização do trabalho.

Castel (1998) constitui um marco na superação da visão dicotômica entre incluídos e excluídos nas abordagens sobre a precarização social. A precarização do emprego e o desemprego - na crise da sociedade salarial fordista - são estratégicos nos processos de reestruturação produtiva, em que a flexibilização/precarização é um elemento central das políticas neoliberais de dominação social, conforme Thébaud-Mony e Druck (2007).

Na verdade, a precarização é um processo multidimensional que altera a vida dentro e fora do trabalho ${ }^{6}$. Nas empresas se expressa em formas de organização pautadas no just in time, na gestão pelo medo, nas práticas participativas forçadas, na imposição sutil de autoaceleração, na multifuncionalidade, dentre outros métodos voltados ao controle maximizado. São processos de dominação que mesclam insegurança, incerteza, sujeição, competição, proliferação da desconfiança e do individualismo, sequestro do tempo e da subjetividade. São afetadas as demais dimensões da vida social, laços familiares e intergeracionais. A desestabilização e a vulnerabilidade sociais conduzem à desvalorização simbólica, com a corrosão do sistema de valores, da autoimagem e das representações da inserção de cada um na estrutura social.

A desestabilização no mundo do trabalho, desde a década de 1980, deu-se com demissões em massa, que reduziram drasticamente os segmentos mais estáveis de trabalhadores, ao lado da expansão de uma multiplicidade de estatutos de assalariamento - explícitos ou não - nas grandes empresas, compondo uma rede de trabalho precário. Muitos demitidos foram reintegrados sob variadas formas de terceirização e ou- tros tipos de precarização dos vínculos contratuais, a exemplo dos contratos temporários, dos contratos em tempo parcial - configurando situações de trabalho frágeis em relação ao seu estatuto anterior. Outros permaneceram no desemprego de longa duração. Assim, as abordagens foram ampliadas, passando a englobar tanto os trabalhadores do núcleo estável, quanto a cascata de terceirizados, compondo uma rede de novas relações de trabalho marcadas pela crescente precarização. Para fins analíticos, pode-se distinguir algumas dimensões deste processo.

A primeira delas diz respeito aos vínculos de trabalho e às relações contratuais. Compreende o processo sociopolítico de perdas de direitos trabalhistas ou do seu usufruto no mundo do trabalho real - descanso remunerado, férias anuais remuneradas, referenciais de jornada de trabalho normal e de horas extras, dentre outros. Envolve, ainda, as perdas de benefícios indiretos - planos de saúde, transporte, alimentação, auxílio educação, dentre outros -, bem como as perdas salariais, em geral, pela não adoção/cumprimento ou defasagem em relação aos acordos coletivos da categoria de trabalhadores mais "estáveis".

Trata-se de uma dimensão do processo de precarização que leva à desestabilização dos estáveis, à perda dos referenciais de proteção social do trabalho, conduzindo "estáveis" e instáveis a metabolizarem, cotidianamente, a competição desenfreada, a insegurança e a instabilidade, terrenos em que prolifera e se move a gestão pelo medo. Druck e Franco (2007) constataram que grandes empresas industriais chegam a ter $75 \%$ de seus trabalhadores regulares sob contratos instáveis (terceirizados) e apenas 25\% “estáveis”. A generalização deste processo resulta num nivelamento "por baixo" do mercado de trabalho, configurando a precarização do emprego (e do mercado de trabalho).

A segunda dimensão concerne à organização e às condições de trabalho que, em todos os setores de atividades, têm se caracterizado pelas metas inalcançáveis e pelo ritmo intenso de trabalho favorecidos pelo patamar tecnológico da microeletrônica. A forte pressão de tempo somada à intensificação do controle ou da instrumentalização do medo à demissão conduzem à intensificação do trabalho. O aumento da competitividade também contribui para esta intensificação, além de, como veremos adiante, acarretar ressonâncias negativas para a sociabilidade e para a saúde mental. A constatação de que a hiperatividade está associada ao desenvolvimento de fenômenos como a compulsividade e a autoaceleração vem revelando processos complexos que têm sido estudados sob várias perspectivas (MARZANO, 2004; DEJOURS, 2004). Acrescente-se a exiguidade dos tempos destinados a pausas no trabalho, repouso, recuperação do cansaço e espaço estrei-

${ }^{6}$ Passet (2002), Castel (2009, 1998), Bourdieu (2001, 1998, 1997), Harvey (1992), Appay e Thébaud-Mony (1997), Hirata e Préteceille (2002), Antunes (2002, 1999), Antunes e Braga (2009), Druck (1999), Druck e Franco (2007), Franco (1997), Thébaud-Mony (2009), Seligmann-Silva (2001; [2011, no prelo]), dentre outros. 
tado do tempo de viver e conviver fora do ambiente de trabalho. A escolha organizacional da polivalência trouxe impactos problemáticos para a identidade dos assalariados que antes experimentavam orgulho profissional por suas especialidades (SELIGMANN-SILVA, 2001). Ao mesmo tempo, a rotatividade no trabalho - entre diversas empresas, com tipos diferentes de contratos - transtornou projetos de desenvolvimento profissional e pessoal de trabalhadores, especialmente dos mais jovens (SENNETT, 1999, 2006). Estas e outras características da organização do trabalho potencializam a multiexposição aos agentes físicos, biológicos, químicos, ergonômicos e organizacionais, favorecendo sofrimento e processos de adoecimento.

A terceira dimensão, estreitamente ligada às anteriores, consiste na precarização da saúde dos trabalhadores. Esta vem incidindo de modo marcante na saúde mental, que é indissociável da saúde como um todo. Trata-se da fragilização - orgânica, existencial e identitária - dos indivíduos pela organização do trabalho com intensificação da multiexposição. Essa fragilização é acrescida das limitações impostas, em muitas empresas, ao bom funcionamento dos SESMTs (Serviços de Engenharia de Segurança e Medicina do Trabalho) no Brasil em nome de uma equivocada contenção de custos. Essas limitações se expressam, por exemplo, nas defasagens de treinamento e de informação sobre os riscos entre segmentos "estáveis" e terceirizados, na diluição das responsabilidades em relação a acidentes, adoecimentos e falhas na prevenção, além do predomínio das medidas de proteção individual em detrimento da proteção coletiva e das políticas preventivas. Por outro lado, observase que a perda de estatuto da maioria dos trabalhadores dentro das empresas - que são os terceirizados, com contratos temporários etc. - conduz a uma maior sujeição às condições aviltantes e (in)suportáveis de trabalho. Diante das metas e dos ritmos acelerados, frequentemente são utilizados "atalhos" e manobras para aumentar a produtividade e manter-se no mercado que fragilizam a segurança e a saúde no trabalho (SILVA; FRANCO, 2007; FRANCO, 1997). Tais aspectos evidenciam os equívocos do economicismo ao menosprezar o que, em verdade, seriam investimentos em saúde e segurança e não "gastos dispensáveis”. Essa postura revela uma negação do valor da proteção à saúde e à vida.

É necessário considerar, ainda, que os tempos sociais do trabalho (ritmos, intensidade, regimes de turnos, hora extra, banco de horas...) encontram-se em contradição com os biorritmos dos indivíduos, gerando acidentes e adoecimentos, destacando-se, internacionalmente, o crescimento de dois grupos de patologias - o das LER/DORT e o dos transtornos mentais. Entre estes, cabe ressaltar: os transtornos do ciclo vigília-sono - comuns em trabalhadores em regimes de turnos al- ternados e de trabalho noturno - que fazem parte da lista de transtornos mentais relacionados ao trabalho de acordo com a Portaria $\mathrm{n}^{\mathrm{o}}$ 1.339/1999 do Ministério da Saúde e, muitas vezes, aparecem associados (em comorbidade) ao quadro de fadiga patológica, também abrangido pela lista oficial; e o Esgotamento Profissional (Síndrome de Burnout), identificado no histórico de muitos casos de quadros depressivos e de processos psicossociais que conduzem aos suicídios e à escalada da dependência do álcool e das drogas ${ }^{7}$.

Ademais, constatações epidemiológicas e clínicas apontam os riscos de hipertensão arterial e doença coronariana configurados pela pressão temporal em profissionais submetidos de forma continuada ao work-stress, entre outras patologias que atingem o organismo pela via psicossomática, nas quais o estresse continuado desempenha papel relevante (HALLQVIST et al., 1998). Vários destes agravos são, portanto, expressão da incompatibilidade entre os tempos sociais do trabalho/vida e a capacidade adaptativa da fisiologia e dos biorritmos humanos. São emblemáticos de modos de viver e de trabalhar socialmente patogênicos. ${ }^{8}$

A quarta dimensão da precarização, fundamental para a consistência do tecido social, compreende a fragilização do reconhecimento social, da valorização simbólica e do processo de construção das identidades individual e coletiva. Numa sociedade em que o trabalho ainda ocupa um espaço/tempo central na vida social e individual, sua precarização dificulta o processo de identificação e construção de si, tornando mais complexa a alienação/estranhamento do trabalho, conforme Antunes (2002). Consolida-se no imaginário social a noção de descartabilidade das pessoas, de naturalidade da insegurança e da competição de todos contra todos, ancorada na fragilização dos vínculos, nas rupturas de trajetórias profissionais, na perda da perspectiva de carreira. Corrosão do caráter, nos termos de Sennett (1999), banalização da injustiça social na perspectiva de Dejours (1999), naturaliza-se toda sorte de exploração, inclusive infantil. Aprofunda-se o processo de coisificação das relações humanas e de humanização das coisas, destratase a vida. Fragilizando-se o reconhecimento social e a valorização simbólica, mina-se a autoestima, sendo atingidas, conforme Seligmann-Silva $(1997,2001)$ e Nardi (2006), as identidades individual e coletiva, bem como a dimensão ética e a dignidade - o cerne do ser humano.

A quinta dimensão afeta a natureza da representação e organização coletiva (sindical). O binômio terceirização/precarização, ao minar a identidade individual e coletiva, conduz à fragilização dos agentes sociais. São os efeitos propriamente políticos da terceirização que pulveriza e enfraquece os sindicatos, ameaçando sua representatividade pela divisão crescente

\footnotetext{
${ }^{7}$ Ver Seligmann-Silva (1994, 2003); Knapp (2006); Linhart (2009), Pezé (2008, 2009); Thébaud-Mony (2009).

${ }^{8}$ Ver Fischer e Lieber (2003); Franco (2003); Passet (2002); National Defense Counsel for Victms of Karoshi (1990).
} 
das categorias profissionais, cada uma com o seu sindicato, com atuações competitivas entre si. Esta fragilização política conduz tanto à discriminação dos terceirizados pela empresa contratante - com espaços demarcados e áreas proibidas - quanto à discriminação entre os próprios trabalhadores - do núcleo "estável" e terceirizados. Ademais, ao minimizar as possibilidades de enfrentamento das condições degradantes, a precarização da organização coletiva aumenta tanto a vulnerabilidade social quanto a individual ${ }^{9}$. A insegurança e a desproteção, vivenciados por todos e por cada trabalhador/a, produzem reações e desdobramentos de diferentes tipos - inclusive transtornos psíquicos ${ }^{10}$.

Vale lembrar que a precarização política, em outra perspectiva, é exposta por Castel (2009) ao analisar a fragilização da cidadania no processo de desmonte de estruturas governamentais e legislações que até os anos 1970 garantiam direitos sociais e políticas de proteção social. Esta precarização concorre para a desproteção que pode tornar-se desamparo, vivenciado na intermitência entre trabalho desregulamentado e desemprego, pelos mais pobres e desprovidos de capital social, especialmente em países nos quais esta falta corresponde, em grande parte, a carências de ordem educacional.

\section{Como se produz a precarização social}

Suposta saída para a crise do fordismo nos anos 1970, a flexibilização do trabalho foi adotada como um dos elementos centrais da reestruturação produtiva e das políticas neoliberais de alinhamento das sociedades urbano-industriais capitalistas ao processo de globalização. Num campo de forças sociais desfavorável ao trabalho pela hegemonia neoliberal, a globalização consolidou o binômio flexibilização/precarização e a perda da razão social do trabalho, com a reafirmação do lucro e da competitividade como estruturadores do mundo do trabalho a despeito do discurso e de programas de responsabilidade social.

A terceirização é uma das principais formas da flexibilização do trabalho mediante a transferência da atividade de um "primeiro" - que deveria se responsabilizar pela relação empregatícia - para um "terceiro", liberando, assim, o grande capital dos encargos e direitos trabalhistas. Na perspectiva da sociologia do trabalho, trata-se de uma forma iniludível de dominação e uma prática de gestão que anula a regulação do mercado de trabalho. A terceirização lança um manto de invisibilidade sobre o trabalho real - ocultando a relação capital/trabalho e descaracterizando o vínculo empregado/empregador que pauta o direito trabalhista - mediante a transferência de responsabilidades de gestão e de custos para um "terceiro".

Na esteira de sua generalização no Brasil, ocorreram sucessivas mudanças na legislação (KREIN, 2003), liberando a empresa das contrapartidas sociais referentes aos direitos trabalhistas. Por outro lado, o enfraquecimento dos sindicatos tem levado a um processo de judicialização das questões sociais (do trabalho), conferindo uma importância suprema à instância jurídica, em particular ao Ministério Público do Trabalho e aos Tribunais Regionais do Trabalho.

Vários tipos de terceirização têm sido detectados desde os anos 1980, abrangendo velhas e novas modalidades: o trabalho a domicílio - seja a forma tradicional, com a subcontratação de trabalhadores autônomos, em geral sem contrato formal, prática recorrente nos setores tradicionais da indústria, seja a forma de teletrabalho no domicílio, a exemplo de microempresas de informática com funcionários trabalhando em suas casas, ou indústria de aparelhos eletrônicos, ou áreas de venda e assistência técnica de várias empresas (LAVINAS et al., 1998); as redes de empresas fornecedoras de componentes e peças (típica da indústria automobilística); a subcontratação de serviços de apoio e periféricos; a subcontratação de empresas ou trabalhadores autônomos em áreas produtivas e nucleares (manutenção); a quarteirização, empresas contratadas para gerir contratos com as terceiras, caracterizando a cascata de subcontratação.

Nos últimos 15 anos, a terceirização cresceu em todos os setores no Brasil, especialmente no setor público e nas empresas estatais, nas seguintes formas: estágios (em empresas e bancos estatais), cooperati-

\footnotetext{
${ }^{9}$ Novos estudos sobre trajetórias de vida e trabalho, desenvolvidos na área de sociologia do trabalho, oferecem embasamento e convergência para o entendimento destes processos de adoecimento mental na atualidade, mobilizados por situações de carência de todo tipo vivenciadas na sequência da perda de empregos estáveis e na intermitência entre emprego precário e desemprego. Ver Hirata e Humphrey (1989); Benoit-Guilbot e Gallie (1992); Elkeles e Seifert (1992); Guimarães (2004); Doray (2006).

${ }^{10}$ As privatizações efetivadas no Brasil, a partir do governo Collor e ao longo dos anos 1990, lançaram muitos antigos funcionários ao trabalho instável, mergulhando-os na precarização. Muitos jamais conseguiram retomar os ofícios para os quais haviam adquirido capacitação e experiência, o que, em numerosos casos, constituiu ponto de partida para o desenvolvimento de quadros depressivos e outros transtornos mentais. Tais processos de desgaste mental se desenvolveram, em alguns casos, ao longo de um desemprego prolongado que era vivenciado como experiência penosa e geradora de profundo desânimo. O constatado nestes antigos funcionários públicos revela alguns impactos específicos decorrentes do desmoronamento de antigas certezas vinculadas à ideia de estabilidade no serviço público. Mas evidencia também aspectos e etapas no adoecimento que apresentam similaridade com os observados em outros trabalhadores atingidos por desemprego prolongado, desde a pesquisa pioneira desenvolvida na Europa durante a depressão de 1929 e nos anos 1930 (JAHODA; LAZARSFELD; ZIESEL, 1975), reencontrados, mais recentemente, em outros países, inclusive no Brasil dos anos 1980 e 1990. Pois a depressão que se instalou em muitos deles se associou também à vivência de uma perda definitiva das perspectivas profissionais e existenciais, conforme Seligmann-Silva (1997, 2001).
} 
vas (destacadamente na área de saúde) e externalização de serviços públicos (da administração direta) para empresas privadas. No setor privado, além das cooperativas, destacam-se o novo trabalho a domicílio (teletrabalho) e as "empresas-filhotes" ou "PJs" (empresas do eu sozinho), que descaracterizam completamente as relações trabalhistas. As cooperativas, em sua maior parte fraudulentas, além de desconfigurarem as imagens do empregado/empregador que representam as relações capital/trabalho, abrigam ex-empregados demitidos das empresas contratantes ${ }^{11}$. Essa nova terceirização - ao deixar de ser uma prática marginal e periférica - conduz a uma profunda metamorfose social, tornando-se estratégia central na gestão das empresas e principal via de flexibilização dos contratos e de controle sobre os trabalhadores.

No processo de flexibilização e precarização, o Estado tem tido papel fundamental através de mudanças permissivas no terreno trabalhista (legalização da terceirização, perda de direitos do trabalho) e liberação dos encargos sociais (KREIN, 2007; CARDOSO, 2003). Configura-se, conforme Appay e Thébaud-Mony (1997), a dupla institucionalização da instabilidade através da precarização econômica e da precarização da proteção social.

Afetando a sociedade como um todo, a precarização do trabalho não se restringe apenas à dimensão econômica. De forma multidimensional, deteriora todo o tecido social, conduzindo a um processo de desfiliação e de despertencimento social, causa direta de vulnerabilidade social e da desfiliação. Para Castel (1998, p. 409): “a precarização do trabalho é um processo central, comandado pelas novas exigências tecnológico-econômicas da evolução do capitalismo moderno". No âmbito de uma sociedade salarial - a despeito da destruição do emprego - o trabalho ainda se mantém como referência para a construção das identidades sociais e passaporte para educação, cultura, lazer, saúde etc. Delineia-se, portanto, uma era de precarização global que consolida a perda da razão social do trabalho, com sérios impactos no imaginário social, gerando violência e adoecimentos, caracterizando uma condição de vulnerabilidade e desfiliação social.

Aprofunda-se a alienação social do trabalho, cristalizando-se o processo de coisificação das relações humanas e de personificação das coisas. São minados os processos de construção das identidades, valori- zando-se o individualismo exacerbado, consumista e desintegrador - nutrindo-se a ilusão de ser feliz pelo ter - e impulsionando-se os indivíduos num voltarse para a exterioridade que conduz a um processo de esvaziamento interior e de negação dos sentimentos e valores humanos, perdendo-se a noção de pertencimento à própria espécie humana.

\section{Indicadores de precarização do trabalho: no mundo, na América Latina e no Brasil}

A Organização Internacional do Trabalho (OIT) apresenta um panorama mundial, de 1990 a 2007 (INTERNATIONAL LABOUR ORGANIZATION, 2008) - período anterior à crise mundial -, que sintetiza o processo de precarização do trabalho, conforme o Quadro 1. Em 2007, a taxa de desemprego no mundo era de 5,7\%, com 179,5 milhões de desempregados. As primeiras estimativas para 2008 previam 190,2 milhões de desempregados, ou seja, um acréscimo de 10,7 milhões de pessoas em situação de desemprego. Nos cenários apresentados pela OIT, a partir da propagação e da mundialização ${ }^{12}$ da crise financeira iniciada nos EUA, as estimativas para o ano de 2009 apontavam para 230 milhões de desempregados no mundo, isto é, um acréscimo de 40 milhões em relação ao ano de 2008.

Em relatório de 2009, a OIT (INTERNATIONAL LABOUR ORGANIZATION, 2009) - embora considere os sinais de recuperação da economia mundial e a queda do emprego inferior ao previsto, decorrentes da intervenção dos governos - alerta que a "[...] crise do emprego está longe de ser superada” (p. vii, tradução livre). Entre outubro de 2008, início da crise, e o final de 2009, em 51 países com dados disponíveis, foram perdidos 20 milhões de postos de trabalho e 5 milhões de trabalhadores se encontravam numa situação extremamente vulnerável, ameaçados de perder o emprego - com jornada de trabalho reduzida, desemprego parcial ou trabalho involuntário em tempo parcial. Além disso, estima-se que 45 milhões de trabalhadores podem ficar fora do mercado de trabalho, especialmente no caso dos pouco qualificados, dos imigrantes, dos mais velhos e dos jovens.

Na América Latina, em relatório da OIT (ORGANIZAÇÃO INTERNACIONAL DO TRABALHO, 2006), a situação já era muito grave, conforme o Quadro 2.

\footnotetext{
${ }^{11}$ Conforme Carelli (2002, 2003); Lima e Soares (2002); Lima (2004, 2007); Piccinini (2004); Gimenez et al. (2003); Druck e Franco (2007). Ver também Araújo (2001); Araúijo e Porto (2004).

${ }^{12} \mathrm{O}$ termo mundialização é amplamente utilizado no pensamento francês contemporâneo, numa perspectiva crítica em relação à globalização. Conforme Chesnais (1996:15): “O termo 'global' permite ocultar uma das características essenciais da mundialização: integrar, como componente central da ação de um capital ‘liberado’, um duplo movimento de polarização que acaba com uma tendência secular que ia no sentido da integração e da convergência. A polarização é, primeiramente, interna a cada país. Os efeitos do desemprego não podem ser dissociados daqueles que resultam dos diferenciais que foram acentuados entre as rendas mais elevadas e as mais baixas, por causa do aumento de renda do capital-dinheiro. A polarização, em seguida, é internacional e cava um fosso brutal entre os países localizados no coração do oligopólio mundial e aqueles que ficam na periferia deste. A economia 'globalizada' é excludente, pois é dirigida pelo movimento do capital e nada mais”.
} 
Quadro 1 Evolução do quadro mundial do trabalho - 1990/2007

\begin{tabular}{|l|l|}
\hline \multicolumn{1}{|c|}{ Indicadores } & \multicolumn{1}{c|}{ Detalhamento } \\
\hline Emprego & Crescimento abaixo da oferta de força de trabalho. \\
\hline Participação dos salários na renda total & $\begin{array}{l}\text { - Sofreu redução em } 51 \text { países, num total de } 75 \text { informantes. } \\
\text { - América Latina e Caribe registraram a maior queda (-13\%). } \\
\text { - Seguidos de Ásia e Pacífico (-10\%) e dos países avançados (-9\%). }\end{array}$ \\
\hline Desigualdade de renda & $\begin{array}{l}\text { - Crescimento da desigualdade de renda em 2/3 dos países. } \\
\text { - Aumento de } 70 \% \text { na disparidade entre os } 10 \% \text { de assalariados com renda } \\
\text { mais alta e os } 10 \% \text { com renda mais baixa* }\end{array}$ \\
\hline Precarização das condições de vida & $\begin{array}{l}\text { Endividamento dos trabalhadores e de suas famílias em países com mer- } \\
\text { cado financeiro sem regulamentação - caso típico dos EUA - estimulados } \\
\text { a investir no mercado imobiliário e de consumo, num quadro de salários } \\
\text { estagnados. }\end{array}$ \\
\hline Precarização do mercado de trabalho & $\begin{array}{l}\text { Crescimento do chamado “emprego atípico" - mediante contratos tem- } \\
\text { porários, por tempo determinado, trabalho informal, sem registro, sem } \\
\text { direitos sociais, salários mais baixos. }\end{array}$ \\
\hline Fragilização política & $\begin{array}{l}\text { A expansão das formas “atípicas" de trabalho é entendida como uma das } \\
\text { vias que pode ter contribuído para o enfraquecimento da capacidade de } \\
\text { negociação dos trabalhadores, especialmente os menos qualificados. }\end{array}$ \\
\hline
\end{tabular}

Fonte: International Labour Organization (2008). Elaboração própria.

* Em 2007, por exemplo, os diretores executivos (CEO) das 15 maiores empresas dos Estados Unidos receberam salários 520 vezes superiores aos do trabalhador médio, aumentando a concentração de renda em comparação à diferença de 360 vezes registrada em 2003.

Situações similares - ainda que com salários mais baixos - podem ser observadas em outros países como Alemanha, Áustria, Hong Kong (China), Países Baixos e África do Sul (INTERNATIONAL LABOUR ORGANIZATION, 2008).

Quadro 2 Alguns indicadores do trabalho na América Latina

\begin{tabular}{|c|c|}
\hline Indicadores & Detalhamento \\
\hline Pobreza & Do total de 551 milhões habitantes, pelo menos 213 milhões são pobres (39\%). \\
\hline Desemprego aberto & Mais de 23 milhões (10\%). \\
\hline Informalidade & Aproximadamente 103 milhões (43\%) trabalham na informalidade. \\
\hline Déficit de emprego formal & Aproximadamente 126 milhões de trabalhadores (53\% da PEA*). \\
\hline Regulação social e direitos & $\begin{array}{l}\text { - Existe alguma legislação e proteção social aos trabalhadores informais em } \\
\text { apenas } 40 \% \text { dos países. } \\
\text { - Em } 2 / 3 \text { dos países existe algum tipo de seguridade social para os trabalha- } \\
\text { dores autônomos. }\end{array}$ \\
\hline $\begin{array}{l}\text { Situação dos jovens } \\
\text { (América Latina e Caribe) }\end{array}$ & $\begin{array}{l}\text { - A população jovem é de } 106 \text { milhões. } \\
\text { - } 58 \text { milhões de jovens estão na PEA. } \\
\text { - } 30 \text { milhões de jovens trabalham na informalidade, correspondendo a 52\% } \\
\text { da PEA. } \\
\text { - } 10 \text { milhões de jovens estão desempregados, } 17 \% \text { da PEA. } \\
\text { - São } 48 \text { milhões de jovens inativos que não trabalham nem estudam e estão } \\
\text { fora da PEA. }\end{array}$ \\
\hline
\end{tabular}

Fonte: Organização Internacional do Trabalho (2006). Elaboração própria.

*PEA: População Economicamente Ativa. 


\section{Alguns indicadores de precarização do trabalho no Brasil}

Em que pese a Agenda do Trabalho Decente ${ }^{13}$, os relatórios mais recentes da OIT indicam que as características mais gerais do mercado de trabalho na América Latina (e no Brasil), embora apresentem redução na taxa média de desemprego de 11,4\% em 1999 para 8\% em 2007, ainda mantêm a tendência e os principais problemas que caracterizam a precarização social do trabalho na região: a) geração insuficiente de postos de trabalho, mesmo com crescimento da população economicamente ativa (PEA); b) crescimento da produtividade restrito a um grupo de setores, com estagnação ou baixo crescimento nos demais, indicando que parte das ocupações foi no trabalho informal; c) o trabalho nos serviços e comércio (terciário) ganha peso; d) aumento do desemprego e da informalidade; expansão dos empregos temporários e sem contrato, com aumento da população ocupada sem acesso à seguridade social; flexibilização das condições para a rescisão dos contratos de trabalho; redução das indenizações por demissão; imposição de limites ao direito de greve; e deterioração dos rendimentos do trabalho num significativo número de países (CEPAL; PNUD; OIT, 2008, p. 11).

Em síntese, configura-se um quadro de desrespeito à Agenda do Trabalho Decente cuja defesa não tem resistido à avassaladora precarização social do trabalho trazida pela mundialização e continuidade das políticas neoliberais nos anos 2000, apesar de avanços pontuais para alguns países, conforme balanço mais recente para o Brasil no período 1992-2007 (ORGANIZAÇÃO INTERNACIONAL DO TRABALHO, 2009), tais como: declínio do trabalho infantil, aumento do trabalho formal, aumento proporcional de idosos que recebem aposentadoria ou pensão, redução do percentual de trabalhadores com duração da jornada acima do normal, crescimento proporcional dos que permanecem mais tempo no emprego, aumento das taxas de sindicalização e aumento da proporção de acordos que efetivaram aumentos reais de salários.

A evolução das taxas de desemprego revela o grau de desigualdade de geração, gênero e etnia no mercado de trabalho. No período 1992-2007, o desemprego masculino cresce de $5,4 \%$ para $6,1 \%$ e o feminino de $8,0 \%$ para $11,10 \%$. Os desempregados brancos aumentam de 5,8\% para $7,3 \%$, enquanto os desempregados negros crescem de $7,2 \%$ para $9,3 \% .{ }^{14}$ É preocupante a situação da juventude. O desemprego dos jovens entre 15 e 24 anos passou de 11,9\% em 1992 para 17\% em 2007, quando a taxa total de desemprego era de 8,3\%. Entre as mulheres jovens, a situação é pior, com 22,1\% de desempregadas, seguidas pelos negros jovens (18\% desempregados) e jovens brancos (15,9\% desempregados). Ademais, 6,4 milhões de jovens não estudavam nem trabalhavam em 2007 (18,8\% do total).

As taxas de desemprego urbano no Brasil, após a eclosão da crise mundial em outubro de 2008, confirmam que não há garantia de superação dos altos níveis de desemprego enquanto não houver uma ruptura com a forma de inserção do Brasil na globalização. ${ }^{15}$ Aos desempregados, somam-se os trabalhadores informais, ${ }^{16}$ vivendo uma condição de extrema vulnerabilidade ou de desfiliação (CASTEL, 1998). São os "sem emprego". ${ }^{17}$ Esses constituem a maioria dos trabalhadores brasileiros, hoje. No período de 1998-2007, ${ }^{18}$ os "sem emprego" chegaram a $62,9 \%$ da população economicamente ativa em 2003, caindo para 54,4\% em 2007 (DEPARTAMENTO INTERSINDICAL DE ESTATÍSTICA E ESTUDOS SOCIOECONÔMICOS, 2010), refletindo a queda do desemprego e o aumento do emprego formal nos úl-

\footnotetext{
${ }^{13}$ Conforme a Agenda do Trabalho Decente, criada pela OIT em 1999, a partir do diagnóstico sobre o "mundo do trabalho" na América Latina nos anos 1990: "O Trabalho Decente é um trabalho produtivo e adequadamente remunerado, exercido em condições de liberdade, equidade, e segurança, sem quaisquer formas de discriminação, e capaz de garantir uma vida digna a todas as pessoas que vivem de seu trabalho (...). Os quatro eixos centrais da Agenda do Trabalho Decente são a criação de emprego de qualidade para homens e mulheres, a extensão da proteção social, a promoção e fortalecimento do diálogo social e o respeito aos princípios e direitos fundamentais no trabalho, expressos na Declaração dos Direitos, adotada em 1998" (ORGANIZAÇÃO INTERNACIONAL DO TRABALHO, 2006, p. 5).

${ }^{14}$ Ressalva-se que o período analisado não inclui as rápidas mudanças no mercado de trabalho em decorrência da crise mundial que se difundiu a partir de outubro de 2008. O relatório justifica que a série histórica analisada se encerra em 2007 em decorrência da não disponibilidade de dados da PNAD 2008, que só ocorreu em setembro/2009. O relatório da OIT foi publicado em 16 de dezembro de 2009.

${ }^{15}$ No período de outubro de 2008 a março de 2009 (INSTITUTO BRASILEIRO DE GEOGRAFIA E ESTATÍSTICA, 2009a), em apenas 6 meses, houve um crescimento de $19 \%$ no pessoal desocupado, passando de 1.743 .000 para 2.082 .000 , correspondendo ao percentual de recuperação do desemprego em 5 anos, no período 2003/2007, quando evoluiu de um total de 2.608.000 desocupados em 2003 para 2.100.000, em 2007 (INSTITUTO BRASILEIRO DE GEOGRAFIA E ESTATÍSTICA, 2009b). A taxa de desocupação aumenta de 7,5\% em outubro de 2008 para $9 \%$ em março de 2009. O setor industrial (extrativo, de transformação e outros) atinge, em abril de 2009, 5,9\% de desocupação, voltando ao patamar de 2003 , ano em que a desocupação atingiu as mais altas taxas de toda a década de 2000. Na região metropolitana de São Paulo, a taxa de desocupação salta de 7,7\%, em outubro de 2008, para 10,5\% em março de 2009, apresentando um crescimento de 36\% de desocupados em apenas 6 meses.

${ }^{16}$ Consideraram-se trabalhadores informais as categorias: assalariados sem carteira, assalariados "não sabe", autônomos, empregadores que não contribuem para previdência, empregadas domésticas sem carteira, trabalho familiar, dono de negócio familiar e outros.

${ }^{17}$ Os desempregados e trabalhadores informais, independentemente das metodologias que estimam o seu efetivo, são denominados pela Agenda de Trabalho Decente da OIT de "Déficit de Emprego Formal” (ORGANIZAÇÃO INTERNACIONAL DO TRABALHO, 2006).

${ }^{18}$ Dados da PED, Pesquisa de Emprego e Desemprego, que engloba 6 regiões metropolitanas (DEPARTAMENTO INTERSINDICAL DE ESTATÍSTICA E ESTUDOS SOCIOECONÔMICOS, 2010).
} 
timos 4 anos, conforme já mencionado anteriormente, mas cuja recuperação foi interrompida pela crise mundial que atingiu o país. ${ }^{19}$

Esse processo confirma a nova configuração do trabalho precário como a tônica do mercado de trabalho. Está presente tanto nos setores mais dinâmicos e modernos do país, nas indústrias de ponta, como nas formas mais tradicionais do trabalho informal, por conta própria, autônomo. Entende-se a precarização como um processo social que instabiliza e cria uma permanente insegurança e volatilidade no trabalho, fragilizando os vínculos e impondo perdas dos mais variados tipos (de direitos, do emprego, da saúde e da vida) para todos os que vivem do trabalho. ${ }^{20}$

\section{SMRT - A psicopatologia da precarização e a psicopatologia da violência}

A partir do quadro acima delineado, deveremos nos deter nos contextos microssociais de trabalho para entender o adoecimento mental relacionado à precarização. A psicopatologia da precarização se configura novo território no âmbito dos estudos da Saúde Mental Relacionada ao Trabalho (SMRT). A psicopatologia da violência extrapola o mundo do trabalho, apesar de profundamente relacionada a ele. Iremos nos deter à violência psicológica, que se expande atualmente no mundo do trabalho. Cabe lembrar, entretanto, que, quanto à natureza dos atos, a violência física está frequentemente associada à psicológica (DAHLBERG; KRUG, 2006).

Inicialmente, tentemos resumir em que consiste a violência no trabalho e suas prováveis causas. A violência foi definida pela Organização Mundial da Saúde (OMS) como "sendo o uso intencional da força física ou do poder”, o que, na interpretação de Dahlberg e Krug (2006, p. 279), "deveria ser entendido como inclusão da negligência e de todos os tipos de abuso físico, sexual e psicológico, tanto como suicídio e outros”. Esta interpretação possui implicações amplas e inclui - entre outras exposições a fatores de risco de natureza física, biológica e química - a negligência patronal que resulta em exposição dos trabalhadores a substâncias neurotóxicas, causa de transtornos mentais dos quais não será possível tratar aqui, assim como não iremos abordar os danos psíquicos decorrentes de traumatismos cranianos provocados em acidentes de trabalho. Os aspec- tos neurotóxicos que levam a transtornos mentais têm sido estudados por outros autores, inclusive no Brasil (CAMARGO; CAETANO; GUIMARÃES, 2005).

Todas estas modalidades são formas de desgaste literal, que afetam as estruturas do sistema nervoso. Nossa abordagem irá restringir-se a um exame contextualizado do desgaste psíquico que se processa nas situações de trabalho a partir de uma outra perspectiva - a das perdas e das deformações que incidem na subjetividade a partir das instâncias sociais, das relações de poder e das instâncias administrativas que regem o trabalho assalariado nas organizações/empresas de todos os setores. O que focalizaremos, portanto, será a violência - dominantemente psicológica - que permeia um desgaste simbólico ou metafórico, o desgaste que empobrece a vida afetiva e o sentido do trabalho para quem o realiza (SELIGMANN-SILVA, 1994, 2004; PAPARELLI, 2009). Desgaste que poderá desembocar em transtornos psíquicos através de um conjunto de mecanismos e mediações.

\section{"Em nome da excelência": a violência embutida nos paradigmas da excelência organizacional}

Na atualidade, a exacerbação da busca de competitividade se reflete na retórica empresarial direcionada à excelência. Retórica que pode ser associada a uma verdadeira ideologia, que tem veiculado a absolutização de um significado da palavra excelência impregnado pelas ideias de perfeição e de superioridade. Excelência entendida como perfeição passou, então, a ser referência para tudo - materiais, processos, métodos e pessoas. Emergiu, assim, uma espécie de coerção à perfeição humana, algo que se transformou em invectiva onipotente e onipresente nas empresas. Esta invectiva se evidencia como profundamente perversa, na medida em que ignora os limites e a variabilidade dos processos fisiológicos e mentais dos seres humanos, como a análise dos princípios e paradoxos da excelência permite constatar (SELIGMANN-SILVA, 2001). Na Europa, a violência da excelência foi bem estudada por Monroy (2000), que pontuou os danos desta "doutrina" à saúde geral e mental dos trabalhadores e, também, descreveu como ela conduz à instalação de uma cultura propícia ao assédio. Em nome da excelência, têm sido minadas as barreiras morais e aberto o espaço ao consentimento das ações perversas.

\footnotetext{
${ }^{19}$ As taxas de informalidade por região metropolitana evidenciam um fenômeno, no período 2000 a 2007, que é a aproximação da proporção da informalidade na região metropolitana de São Paulo/SP, maior centro industrial do país, com a informalidade da região metropolitana de Salvador/Bahia, fortemente marcada pela tradição de trabalho informal. Em 2007, essas taxas se igualaram: 41,5\% em Salvador e 41,8\% em SP. Esse quadro reflete uma das dimensões da precarização - o trabalho informal - que atualmente atinge tanto as regiões mais desenvolvidas do país, a exemplo de São Paulo, quanto as regiões mais tradicionalmente marcadas pela precariedade.

${ }^{20}$ Deve-se observar que persistem velhas formas de trabalho precário anteriores ao capitalismo ou típicas da primeira revolução industrial: o trabalho escravo e o trabalho infantil. Práticas fortemente denunciadas pela OIT têm sido objeto de fiscalização especial do Ministério do Trabalho e Emprego, tendo resultado em resgates de trabalhadores e feito recuar abusos do capital em diferentes regiões do país. Em 2008 , foram resgatados 5.018 trabalhadores em condição de trabalho forçado (BRASIL, 2009). O trabalho infantil (de 5 aos 14 anos) vem apresentando uma queda em todos os anos desde 1998, quando representava 8,9\%, chegando a 4,9\% em 2007 (ORGANIZAÇÃO INTERNACIONAL DO TRABALHO, 2009).
} 
A violência da excelência em geral é marcada pela sutileza e imposta de modo a disfarçar a dominação, por exemplo, sob discursos e projeção de cenários de um futuro promissor para a empresa e para seus colaboradores (expressão que oculta a relação de poder embutida na subordinação capital/trabalho). ${ }^{21}$

A imposição dos paradigmas da excelência acontece juntamente com a imposição do medo de discordar, já que o dilema é aderir ou ser excluído. Isso dá lugar a uma verdadeira coação ao fingimento - pois todos precisam mostrar-se excelentes, energizados para cumprir as metas e, por conseguinte, fingir (até para si mesmos) que estas são sempre alcançáveis. ${ }^{22}$

Béatrice Appay (2005) nos mostrou como a violência psicológica pode ser encoberta pelo manto de uma falsa liberdade - a autonomia controlada - isto é, uma autonomia autorizada e estimulada em tudo o que favoreça de modo imediato o alcance das metas empresariais - contanto que se restrinja a estes desígnios. Liberdade ilusória que implica, inclusive, no afrouxamento do autocontrole de tendências perversas até então submetidas à autocensura. A autora esclarece de que modo a violência se inscreve, atualmente, na organização do trabalho.

A retórica empresarial é refletida nas práticas de treinamento adotadas. Uma nova escala de valores perpassa os principais paradigmas veiculados de forma sedutora, visando obter a adesão incondicional por parte dos novos colaboradores. Vejamos, a seguir, os principais paradigmas e as invectivas que passaram a reger a vida das empresas e as daqueles que nelas trabalham.

1. Competitividade maximizada: A maximização da competitividade da própria empresa, repetimos, é a grande finalidade do incremento à excelência. Ao ser transferida para os indivíduos, essa exacerbação da competitividade pode se tornar feroz. Além de incrementar o individualismo, cria também a violência. Para obter o máximo de cada um, estimula-se a onipotência e o narcisismo adormecidos, levantando a crença de que os potenciais individuais são ilimitados, de modo que, além de não mais respeitar a integridade dos demais, o indivíduo deixa de ver os riscos de seu próprio desgaste (SENNETT, 2006). Sennett mostra que a ameaça de degradação paira sobre as instâncias coletivas nos ambientes de trabalho, que antes mantinham vivos, mesmo com esforço, a reciprocidade quanto ao respeito, à confiança, ao reconhecimento profissional e humano - esteios para a construção coletiva de normas consensuais que constituíam, ao mesmo tempo, marco éti- co e uma referência para a atividade de trabalho fundada na experiência do ofício. As práticas de gestão adotadas fomentam a indiferença pelo destino dos demais, que se transformam em rivais a serem derrotados ou mesmo excluídos.

2. A supervalorização da flexibilidade é certamente o aspecto que tem sido alvo do maior número de estudos críticos, ${ }^{23}$ pois, além do papel que assume na precarização do trabalho, contribui para incrementar a tensão e a fadiga ligadas aos esforços de adaptação continuada à cascata de mudanças de todo tipo. Muitas imposições organizacionais desprezam os conhecimentos sobre fisiologia, psicologia do trabalho e da aprendizagem e, ao mesmo tempo, empobrecem a identidade profissional e o sentido do trabalho para aqueles que são obrigados a abandonar a capacitação e a experiência profissional adquiridas para se tornarem flexíveis e polivalentes.

A flexibilidade tornou-se verdadeiro imperativo ideológico que não atinge apenas estruturas e práticas organizacionais, mas também ativa fortemente a dissolução de valores essenciais da ética individual e institucional, pois a injunção imperiosa é de que tudo seja flexibilizado - até o caráter e o ser profundo de cada um. Este é certamente o impacto mais avassalador $^{24}$ da absolutização do paradigma da flexibilidade, impacto que incide fortemente na saúde e na vida mental.

3. Mudança e inovação continuadas: Grey publicou na Inglaterra, em 2002, artigo que teve grande repercussão nos meios administrativos e que contém crítica profunda e desmistificadora sobre o que o autor denominou fetiche da mudança permanente (GREY, 2004). A invectiva de inovar continuadamente está associada a esse fetiche, estendendo-se aos seres humanos que trabalham - e que devem ser não apenas renovados em suas características e capacidades, como também ser substituídos assim que se desgastem, seja por cansaço, adoecimento ou pelo próprio avançar da idade. Deste modo, o assalariado é coisificado, tornado descartável como qualquer ferramenta desgastada.

Luc Boltanski (2008) mostra como a sucessão das mudanças vem impedindo, em geral, uma crítica que se torne capaz de mobilizar enfrentamentos solidários. Michael Burawoy (2000), entretanto, identifica alguns sinais de que estes enfrentamentos começam a reaparecer, pelo menos entre os trabalhadores do setor de serviços.

\footnotetext{
${ }^{21}$ No Brasil, Lima (1996) e Bernardo (2009) evidenciaram com clareza, em várias empresas, esta dominação mascarada e outros aspectos do contraste entre o discurso sedutor e práticas gerenciais potencial ou efetivamente adoecedoras.

${ }^{22}$ Este aspecto tem sido constatado em estudos críticos sobre a gestão direcionada pelos imperativos neoliberais (MONROY, 2000), assim como em depoimentos de trabalhadores adoecidos (PEZÉ, 2008).

${ }^{23}$ Bourdieu (1998); Heloani (2003); Seligmann-Silva (2001), entre outros.

${ }^{24}$ Usamos a palavra "avassalador" considerando seu sentido pleno: transformar em vassalo - expressão de submetimento máximo.
} 
4. O paradigma da rapidez também mantém consonância face à idealização da velocidade na cultura contemporânea. Corresponde assim, uma vez mais, ao ideal de onipotência e perfeição que coloca marca infamante em todos os desgastados e cria intolerância aos que não são velozes por oscilações da saúde ou porque estão sendo atingidos pelo envelhecimento. Assim, a maximização da intensificação do trabalho obriga o trabalhador a romper seu equilíbrio psico-orgânico. Na atualidade, em muitas organizações, a impaciência é institucionalizada em detrimento do trabalho bem feito. Estas são as instituições aceleradas, em que as rápidas mudanças sequer permitem o aprendizado correto do trabalho que se modifica a cada passo, tornando-se fonte de frustração e angústia (SENNETT, 2006). Portanto, o paradigma da rapidez também se articula ao anterior, para que a mudança permanente se faça velozmente, sem que importem a natureza e a complexidade do trabalho, sem, sequer, haver o tempo necessário para criar familiaridade com o trabalho - aspecto importante para que se desenvolva a engenhosidade e evite a penosidade (SATO, 1991).

\section{As formas de violência psicológica: assédio moral e assédio organizacional}

A violência psicológica pode acontecer de forma esporádica ou em momentos críticos, em conflitos interpessoais ou quando situações geradoras de grande ansiedade criam descontrole emocional, com explosões de raiva. Mal-estar, frustração, ressentimento e mesmo adoecimento podem ser produzidos em tais ocasiões, mas não se trata de assédio (HIRIGOYEN, 1998, 2002). Quando a dignidade de alguém é sistemática e deliberadamente atacada, configura-se o assédio moral, que pode ser individual ou coletivo. Soboll (2008), entre outros, distingue o assédio organizacional (resultante de estratégia organizacional) do assédio moral propriamente dito, no qual os responsáveis podem ser individualizados. Nem sempre é fácil fazer a distinção destas duas modalidades.

A ideia de que o assédio seja expressão direta do sadismo e da insensibilidade de alguém em posição de chefia foi muito disseminada e chegou a constituir consenso - logo após a divulgação do primeiro livro de Hirigoyen sobre o assunto no início dos anos 1990 (HIRIGOYEN, 1998). A dominância do assédio organizacional tornouse agora nítida. Uma interpretação menos individualizadora do assédio também pode contribuir para evitar uma centralização na vitimização, visto que esta tem ocasionado, simultaneamente, dois prejuízos: a) obstaculizar a percepção das reais origens da escalada do assédio e, por conseguinte, o enfrentamento coletivo do problema; b) dificultar a superação dos danos psíquicos daqueles que são levados a se concentrar no papel de vítima. Superação que exigiria uma "despsicologização do conflito", expressão de Davezies (2004). ${ }^{25}$

As finalidades do uso intencional da violência psicológica são de duas ordens: obter a submissão às imposições de produtividade ou provocar a demissão. Às vezes, as duas finalidades - obter submissão e excluir - estão imbricadas. A violência pode ser uma pressão destinada a induzir pedido de demissão - ao gerar uma situação insuportável ao empregado. Mas, não raro, os constrangimentos são impostos como forma de provocar descontrole emocional e explosões agressivas que ensejem uma demissão por justa causa (FREITAS; HELOANI; BARRETO, 2008).

Um exemplo é o desígnio de suscitar demissão e exclusão da empresa de grupos que se tornaram "descartáveis" ou indesejáveis, como após o adoecimento coletivo por LER/DORT (MAENO, 2001). Não importa a modalidade do assédio: o prolongamento de qualquer situação de assédio, principalmente na ausência de suportes afetivos e sociais, levará à vulnerabilização da saúde e potencializará os riscos de adoecimento mental ou do tipo psicossomático.

\section{Transtornos mentais vinculados à pre- carização e à violência}

É possível identificar a escalada de um conjunto de transtornos mentais que tem sido reconhecido nos estudos de SMRT, em sua relação à violência contida na precarização social e do trabalho. Essa categorização tem como fundamento estudos clínicos e sociais realizados em diferentes países, inclusive no Brasil, ao longo das últimas três décadas, e tem sido objeto de revisão e sistematização recentes. ${ }^{26}$ Estão incluídos neste grupo: quadros depressivos; esgotamento profissional (Burnout); ${ }^{27}$ o transtorno de estresse pós-traumático (TEPT);28 dependência de bebidas alcoólicas e outras substâncias (drogas ilegais e psicotrópicos).

\footnotetext{
${ }^{25}$ Hirigoyen (2002); Appay (2005); Soboll (2008); Pezé (2008); Davezies (2004), dentre outros.

${ }^{26}$ Lhuilier (2007); Dejours (2007); Pezé (2008); Doniol-Shaw (2001); Huez; Sandret (2001); Elkeles; Seifert (1992); Seligmann-Silva (2003; [2011, no prelo]); Huws (2003); Merlo; Mendes (2009). Há também livro inédito, no prelo, de Miguel Matrajt intitulado Travail, subjectivité et societé.

${ }^{27}$ Apesar de não constar como diagnóstico da CID-10 (WORLD HEALTH ORGANIZATION, 1992), a síndrome do Burnout faz parte, no Brasil, da lista de 12 transtornos mentais relacionados ao trabalho que se tornou oficial a partir da Portaria no 1.339/1999 do Ministério da Saúde (BRASIL, 2001).

${ }^{28}$ Invisibilidade do TEPT nos registros previdenciários do Brasil: os dados do Instituto Nacional de Seguridade Social (INSS) sobre causas médicas dos benefícios em auxílio doença e auxílio acidentário não incluem avaliação específica do código F43.1, que é o referente ao TEPT. Constata-se, assim, a invisibilidade dos casos de TEPT relacionado ao trabalho nas estatísticas brasileiras da Previdência Social e consequente prejuízo para a análise dos impactos da violência na saúde mental.
} 
Na atual CID-10 (WORLD HEALTH ORGANIZATION, 1992), não existe uma categoria diagnóstica que corresponda aos quadros paranóides não psicóticos cada vez mais encontrados na prática dos serviços de saúde que atendem trabalhadores. Estes quadros aparecem como expressões clínicas das vivências de ameaça e perseguição no cotidiano de trabalho e se configuram, talvez, como uma modalidade da neurose da excelência, que foi descrita na França por Aubert e Gaulejac (1991). Constituem o produto de um clima organizacional de desconfiança, incerteza e intimidação em que o controle se configura como vigilância que não dá trégua. Os medos se multiplicam e criam um estado de tensão e alerta permanentes, no qual o trabalhador tem vivências de estar sempre sob ameaça, sujeito a ciladas, isolado, silenciado e sem poder confiar em ninguém. Surgem ideias de autorreferência, insônia e distúrbios psicofisiológicos.

\section{Mediações ao longo do itinerário do desgaste mental no trabalho precarizado}

Estamos diante do entendimento de que os processos políticos, econômicos e culturais que terão ressonância no desgaste mental dos trabalhadores percorrem as passagens que se apresentam entre a esfera macrossocial, os contextos nacionais e as várias estruturas internas das organizações até alcançarem os indivíduos em diferentes situações concretas de trabalho.
Na impossibilidade de examinar aqui a imensa variedade de mediações existentes em diferentes atividades e situações, restringimos-nos a enfatizar a importância de alguns tipos de mediação comuns a diferentes atividades: os suportes institucionais e legais efetivamente atuantes na proteção social, os movimentos políticos e sociais, as defesas psicológicas coletivas e individuais que podem retardar ou mascarar o mal-estar ou mesmo a expressão dos adoecimentos, por exemplo, defesas psicológicas individuais ou coletivas voltadas ao disfarce ou à negação de sofrimento físico, ético-moral ou psíquico. Vale assinalar que as resistências efetivadas através de enfrentamentos coletivos das condições adoecedoras, ao mesmo tempo que mobilizam conscientização e solidariedade, potencializam o polo da vitalidade. Tratase de resistências analisadas em muitos estudos, no Brasil e no mundo (SILVEIRA, 2003). Já a perda da razão social do trabalho tem como ressonância a perda do sentido do trabalho. Eé esta perda de sentido que: a) constitui o cerne das formas de desgaste mental originadas pela metamorfose perversa da organização do trabalho; b) consubstancia formas de desgaste mental que conduzem às depressões e ao burnout, além de atuar poderosamente na patogênese de outros transtornos psíquicos e psicossomáticos. ${ }^{29}$

Sem pretender examinar todos os meandros da trama complexa da produção do desgaste mental no trabalho precarizado, nos deteremos em algumas mediações importantes para o olhar do profissional de saúde (Quadro 3).

Quadro 3 Patamares e mediações na dinâmica dos transtornos psíquicos relacionados ao trabalho

\begin{tabular}{|l|l|}
\hline \multicolumn{1}{|c|}{ Patamares e mediações } & \multicolumn{1}{c|}{ O que émobilizado } \\
\hline $\begin{array}{l}\text { Passagem do patamar microssocial ao individual nas } \\
\text { situações de trabalho }\end{array}$ & $\begin{array}{l}\text { Processos psicossociais decorrentes da organização, dos vínculos, do } \\
\text { tipo de gestão, dos processos de trabalho e dos graus de comunicação } \\
\text { significativa, incluindo as defesas psicológicas e as resistências socialmente } \\
\text { articuladas. }\end{array}$ \\
\hline $\begin{array}{l}\text { Dinâmicas no nível do indivíduo como unidade bio- } \\
\text { psicossocial em que se desenvolvem interações entre } \\
\text { corpo/vida mental*âmbito social }\end{array}$ & $\begin{array}{l}\text { Em contextos de pobreza: } \\
\text { Vulnerabilidades do corpo mal nutrido, fisiologia precarizada por más } \\
\text { Corpo extenuado e isolamento por fadiga, falta de acesso à participação } \\
\text { social, à oportunidades de conhecimento, à conscientização política, à } \\
\text { sociabilidade e a lazer significativos. }\end{array}$ \\
\hline $\begin{array}{l}\text { Em outros contextos. } \\
\text { Dinâmica intrapsíquica }- \text { que é apoiada nos suportes } \\
\text { tempornalizados no passado pessoal e, ao mesmo interação continuada com os outros } \\
\text { patamares sociais }\end{array}$ & $\begin{array}{l}\text { Fenômenos subjetivos: afetos (sentimentos, emoções e eventualmente } \\
\text { paixões); valores conectados a estes afetos; defesas e resistências individuais. } \\
\text { Mobilização dos sentimentos e emoções face às percepções: a) de rupturas } \\
\text { da ética e da sociabilidade; b) de ataques à dignidade; e c) de desproteção. }\end{array}$ \\
\hline
\end{tabular}

*Vida mental designa o entrelaçado complexo cognitivo-afetivo. 
Diferentes fenômenos vinculados à humilhação, à vivência de incerteza, à injustiça e, em especial, a imposições, direcionados à violação de valores éticos e morais, encontram-se articulados a algo que ocupa o pano de fundo da precarização do trabalho: o esvaziamento vivenciado a partir do empobrecimento do significado do trabalho.

Essa agressão ao sentido do trabalho foi vista por Freudenberger (1987) como uma questão central na gênese da síndrome que ele descreveu: o esgotamento profissional (burnout). Outros autores, como Clot (2008), percebem-na como eixo central na dinâmica que origina as depressões no trabalho contemporâneo em um processo profundamente conectado à perda do reconhecimento.

No esgotamento profissional ou burnout, a crise ocorre diante do desmoronamento não apenas de uma visão idealizada de si mesmo e de uma missão (como dizia Freudenberger), mas também pela percepção de que foi abalado o caráter ético que dava sentido às atividades realizadas. Esse aspecto é especialmente visível quando se trata de um trabalho de natureza social, por exemplo, no ensino, na saúde e na assistência social.

O desgaste da esperança pode tornar-se extremamente preocupante na medida em que está profundamente associado ao risco de suicídio. Não apenas as depressões, mas também os demais transtornos psíquicos aqui relacionados à violência têm levado ao suicídio em casos analisados em profundidade. ${ }^{30}$ Desde a década de 1990, entidades sindicais e a mídia da Alemanha e da Itália denunciam a violência organizacional que culmina em suicídios e, até mesmo, em assassinatos.

\section{Vulnerabilidade preexistente e vulne- rabilização das transformações atuais: contextos de pobreza}

Ainda temos poucos estudos com enfoque mais direcionado aos contextos de pobreza no âmito da psicopatogênese dos transtornos mentais relacionados ao trabalho. Por isso realizamos a escolha de lembrar aqui os trabalhadores destes contextos, deixando de focalizar outros já mais estudados nos estratos socioeconômicos médios.

No trabalho precarizado, em contextos onde predominam trabalhadores pobres e de pouca escolaridade, estas duas condições - pobreza e pouca instrução - estabelecem uma vulnerabilidade maior ao adoecimento, tanto do ponto de vista orgânico (pela deficiência nutricional, por exemplo), quanto pela falta de acesso ao conhecimento e/ou a instâncias que ofereçam suporte social. Assim, os contextos de pobreza favorecem, simultaneamente, a intensificação da dominação em que há uso de violência e o aumento da vulnerabilidade ao adoecimento, pois a falta de alternativas, nestes casos, costuma condicionar uma submissão que prolonga a situação desgastante até o esgo- tamento (na fadiga patológica ou no burnout), a depressão ou outros adoecimentos. O estreitamento do mercado de trabalho e o desmonte das alternativas institucionais de proteção social alimentam esse processo. No caso de trabalhadores migrantes que vivem sozinhos, também faltam geralmente os suportes afetivos, o que favorece a desestabilização psíquica, especialmente para aqueles que estão submetidos à discriminação e ao isolamento social nos locais de trabalho ou na situação de desemprego. Deve ser considerado, também, o valor - na proteção contra a desestabilização da saúde mental - dos apoios sociais e afetivos providos pelas famílias e, no caso brasileiro, muitas vezes pelas comunidades de conterrâneos - que oferecem casa e auxílio alimentar aos desempregados.

Na constituição dos agravos aqui considerados, antes do desencadeamento e do surgimento de quadros clínicos caracterizados, existe, quase sempre, uma fase de vulnerabilização. O TEPT é o único dos transtornos mencionados no qual nem sempre é possível detectar essa vulnerabilização antes do evento traumático que tem sido frequentemente considerado essencial ao diagnóstico.

Esta fase de vulnerabilização é marcada por perdas e impedimentos resumidos no Quadro 4.

Além das perdas e dos impedimentos, entre outros aspectos na gênese de transtornos psíquicos no contexto da precarização social, não se pode deixar de mencionar o trauma sofrido em situação de trabalho, considerando aqui, especialmente, os eventos traumáticos, em que a violência toma a forma de ameaça iminente à vida (sofrer assalto no trabalho; vivenciar um acidente grave) e que podem levar ao desencadeamento de quadros de estresse pós-traumático (TEPT) e outros transtornos (depressões e mesmo quadros de psicose).

No contexto da precarização, é necessário considerar, também, o fenômeno do presenteísmo, em que muitos assalariados, mesmo adoecidos, não revelam seus sintomas no trabalho nem procuram benefícios pelo medo de perder o emprego ao terminar o período de afastamento. Aliados a esse temor, às vezes fortes mecanismos de negação psicológica dos sintomas fazem com que nem os próprios assalariados reconheçam os agravos sofridos por sua saúde. Em muitos casos, as pessoas ficam muito tempo sem procurar qualquer tratamento. Deste modo, os processos mórbidos evoluem, cronificam e se agravam. Um conjunto de estudos indica que especialmente a morbidade psiquiátrica esteja tendo, em todos os países, um ocultamento importante e desastroso em seus desdobramentos. Relatório recente demonstra preocupação na Europa e nos Estados Unidos com a expansão do presenteísmo e os custos daí decorrentes (BADURA, 2009). O agravamento da patologia invisibilizada, quando a intensificação dos sintomas atinge finalmente um grau impossível de conciliar com o trabalho, culmina em afastamento prolongado - que implica em altos custos previdenciários, sociais e humanos. Outra decorrência é a de registros de morbidade falseados pelo presenteísmo. ${ }^{31}$

\footnotetext{
${ }^{30}$ Ver Thébaud-Mony (2007, 2009); Dejours (2004); Dejours; Bègue (2009); Santos (2009); Floen; Elkit (2009).

${ }^{31}$ Conforme Badura (2009), novos cuidados se impõem à análise de registros utilizados em Saúde Pública, mascarados pelo presenteísmo, com perda de confiabilidade das bases de dados.
} 
Quadro 4 Perdas e impedimentos na precarização social e do trabalho

\begin{tabular}{|c|c|}
\hline Fase de vulnerabilização & Detalhamento dos impactos \\
\hline Perda de suportes sociais e afetivos & $\begin{array}{l}\text { Importante na gênese de vários agravos, precede a eclosão do burnout e de quadros } \\
\text { depressivos. Relevante no adoecimento por assédio moral, inclui perdas de suportes de } \\
\text { sobrevivência social digna por retrocessos de ordem legal devidos à precarização social. }\end{array}$ \\
\hline Perda de confiança & $\begin{array}{l}\text { Desenvolve-se tanto com a exacerbação da competição interna, quanto pela percepção } \\
\text { da onipresença da falsidade. Agrava-se na iminência e na sequência de enxugamentos } \\
\text { (PDVs ou outras formas). }\end{array}$ \\
\hline $\begin{array}{l}\text { Impedimento do repouso e da recupera- } \\
\text { ção do cansaço }\end{array}$ & $\begin{array}{l}\text { O medo, a fadiga acumulada e as perturbações do sono, acrescidos pela percepção } \\
\text { da própria queda de desempenho, levam à ansiedade, à irritabilidade e ao mal-estar } \\
\text { crescente. É quando, muitas vezes, emergem a autoacusação, a autodesvalorização e } \\
\text { vivências de fracasso que configuram o caminho para as depressões e outros transtor- } \\
\text { nos psíquicos e psicossomáticos. O mal-estar continuado atinge - pela via do estresse } \\
\text { ou por outros meios - o funcionamento (fisiologia) do organismo e, com o tempo, pode } \\
\text { levar a alterações estruturais (enfarte cardíaco, por exemplo). }\end{array}$ \\
\hline Atividade impedida & $\begin{array}{l}\text { Atividade impedida no trabalho dominado é aquela que corresponde ao trabalho sau- } \\
\text { dável, vitalizador.* No trabalho intensivo, não há tempo para pensar nem para entrar em } \\
\text { contato com os próprios sentimentos e fantasias. O medo de divergir e receber sanções } \\
\text { intensifica a restrição imposta pela velocidade. Desta forma, é potencializado o impedi- } \\
\text { mento às reflexões de ordem crítica. Em suma, na atividade impedida estão boicotados, } \\
\text { conjuntamente: iniciativa ao agir e ao pensar a partir do próprio ser, a formação de } \\
\text { juízos críticos e a mobilização dos afetos vitais (CLOT, 2008). }\end{array}$ \\
\hline Renúncia à ética & $\begin{array}{l}\text { A dominação - na forma pela qual vem sendo exercida - ao violentar a vida mental e } \\
\text { ao impor a priorização da meta empresarial, pode levar ao sacrifício da ética pessoal e } \\
\text { profissional. }\end{array}$ \\
\hline $\begin{array}{l}\text { Perdas relacionais ao longo do processo } \\
\text { de isolamento dos demais no ambiente } \\
\text { de trabalho }\end{array}$ & $\begin{array}{l}\text { Ocorre em várias situações: a) no assédio moral; b) no trabalho intensivo em que a } \\
\text { fadiga e, mais adiante, a irritabilidade prejudicam o diálogo e o convívio social; c) por } \\
\text { injunção organizacional que estimula a competição e o individualismo. }\end{array}$ \\
\hline Silenciamento & $\begin{array}{l}\text { Expresso no impedimento de manifestar-se, exercer crítica, fazer sugestões. Relacio- } \\
\text { nado a outro medo: o de não aguentar, cometer erros ou adoecer. É o que acontece } \\
\text { quando o trabalhador, sem ter possibilidade de contestação, percebe a própria desvi- } \\
\text { talização e a lentificação do desempenho. }\end{array}$ \\
\hline Perda da possibilidade de autenticidade & Sentir-se ou ser explicitamente coagido à falsidade e à mentira. \\
\hline Impedimento a ser reconhecido & $\begin{array}{l}\text { A avaliação/reconhecimento é mais em função da adesão organizacional (obediência } \\
\text { estrita e incondicional) às diretrizes/metas do que ao trabalho realizado e ao empenho } \\
\text { de realizar o trabalho bem feito e fiel aos princípios éticos. Os critérios de avaliação, } \\
\text { atualmente, com frequência, ferem o sentido do trabalho. }\end{array}$ \\
\hline $\begin{array}{l}\text { Perda do respeito/ser desconsiderado e } \\
\text { ferido em sua dignidade }\end{array}$ & $\begin{array}{l}\text { Impossível ser significativo um trabalho no qual o indivíduo é desrespeitado em sua dig- } \\
\text { nidade humana. A preservação da dignidade também é essencial à estabilidade psíquica } \\
\text { (DORAY, 2006). }\end{array}$ \\
\hline Despossessão de si mesmo & $\begin{array}{l}\text { A expropriação da subjetividade foi identificada em } 1981 \text { por Doray }(1981,2006) \text { em } \\
\text { trabalhadores de linha de montagem. O mesmo autor, agora, observa que o agravamento } \\
\text { da dominação se fez acompanhar por um tipo de desrespeito à dignidade que também } \\
\text { suscita a despossessão de si mesmo, o que também é afirmado por Le Blanc }(2007) \text {. }\end{array}$ \\
\hline Invisibilização & $\begin{array}{l}\text { Os trabalhadores deixam de ser percebidos como pessoas presentes, são coisificados. } \\
\text { Atinge certas categorias de trabalhadores pesquisadas por Costa (2002), que analisou } \\
\text { garis em São Paulo, e por Le Blanc (2009), na França. }\end{array}$ \\
\hline
\end{tabular}

*Trabalho vitalizador: sintetizando a visão de três pensadores, Spinoza (2007), Sainsaulieu (1988) e Clot (2008), é aquele no qual o ser do trabaIhador está engajado - de forma plena e sem constrangimentos -, usando livremente a própria experiência, inteligência e criatividade ao mesmo tempo em que mobiliza desejos e fantasia. Um trabalho no qual possa ser reconhecido e reconhecer-se. 
Pensando no caso brasileiro, possivelmente poderíamos considerar que a instauração da prevenção secundária - detecção e tratamento precoces, como recomenda o relatório - já constituiria um avanço inicial. Para que se criasse consenso a respeito, seria necessário, primeiramente, superar a ideologia da excelência e os preconceitos decorrentes contra os assalariados que apresentam sinais de desgaste, revelando seus limites humanos. Limites que, por escaparem aos imperativos de excelência, os assalariados tentam desesperadamente ocultar, temendo a condenação ao desemprego.

\section{Reflexões sobre o trabalho contemporâ- neo: despertencimento social e desen- raizamento em relação à natureza}

É necessário lembrar que a flexibilização do trabalho ocorre sobre um patamar fossilista de tecnologias de base microeletrônica. ${ }^{32}$ Esta combinação de bases tecnológicas e política de gestão do trabalho encerram dois processos sociais importantes que têm raízes profundas e são inerentes ao capitalismo: o despertencimento/desfiliação social e o desenraizamento humano em relação à natureza.

O processo de despertencimento social, como vimos, é produzido no seio da flexibilização, pelo binômio terceirização/precarização. Conduz à fragilização dos laços e dos referenciais de pertencimento social, levando, no limite, à desagregação social, com a proliferação de toda sorte de violência social, sofrimento e adoecimento, com destaque para as patologias musculoesqueléticas (LER/ DORT) e os transtornos mentais cada vez mais frequentes, sem limites de classe, gênero, etnia, idade etc.

O avanço da precarização e do despertencimento social tende a apagar os referenciais de limites biopsicossociais no imaginário social, a exemplo das noções de jornada de trabalho normal e de hora extra, bem como do trabalho infantil. Vale lembrar que são marcos construídos pelos movimentos sociais e consolidados na regulação social assumida pelo Estado desde o final do século XIX até a era fordista na década de 1970. São referenciais de grande importância, pois traduzem uma etapa civilizatória marcada pelo reconhecimento institucional de ciclos e limites biopsicossociais que perpassam a existência humana e a lida cotidiana. Contemplam, ainda que palidamente, as diferenças de fases da vida humana e gênero - infância, envelhecimento, morte - suas peculiaridades e possíveis rupturas por acidente, adoecimento etc. A desregulação social em curso é um processo de apagamento dessas noções culturais que protegem a vida humana - de crianças, jovens, adultos, idosos homens e mulheres - revelando uma das faces da perda da razão social do trabalho.

O reconhecimento dos limites biopsicossociais dos seres humanos no trabalho (expressos nas leis trabalhistas, por exemplo) é fruto de um longo processo, nada linear. Apesar dos avanços em relação aos primórdios das sociedades urbano-industriais neste âmbito, chama a atenção um contínuo processo histórico de inversão das relações da humanidade na/com a natureza no seio destas sociedades que afeta tal reconhecimento.

Trata-se da consolidação dos padrões de produção e consumo fossilistas, fruto das três revoluções industriais que romperam com todas as formas de civilização anteriores, invertendo radicalmente a relação da humanidade com/na natureza. Através desta ruptura, estabelece-se uma nítida linha de continuidade no seio das sociedades capitalistas urbano-industriais desde o século XIX, em termos da violação dos limites dos ecossistemas e da destruição ambiental - da camada de ozônio, contaminações químicas progressivas, aquecimento global, desmatamento etc. -, revelando uma civilização inerentemente avessa à natureza e à vida. ${ }^{33}$

Os acidentes industriais e as contaminações ${ }^{34}$ de ar, terra e água marcam uma página virada na história da humanidade, revelando que as sociedades capitalistas flexíveis - permanentemente em crise social e ambiental - estão assentadas num padrão de produção e consumo que dissemina, cotidianamente, inúmeras substâncias neurotóxicas, cancerígenas, teratogênicas e mutagênicas - sem controle -, rompendo os limites de tempo (atingindo gerações futuras) e de espaço, envolvendo todo o planeta e seus ecossistemas. Deve ser lembrado, ainda, que muitos produtos químicos - metais pesados e outros - além de atingirem a saúde em geral, apresentam danos específicos e graves para o sistema nervoso e a saúde mental.

A inversão em relação aos ciclos da natureza é um processo contínuo de, no mínimo, quatro séculos. Este conduz a um despertencimento - socialmente produzido - que não se confunde com o despertencimento social anteriormente visto. Trata-se de um despertencimento de outro tipo: é um desenraizamento - interior e exterior - do ser humano em relação à natureza, é um desligamento profundo de si próprio que leva à dificuldade crescente em reconher-se enquanto ser da espécie. É a alienação de si mesmo enquanto ser humano gerado na/com a natureza. Este desenraizamento se expressa, por exemplo, na ruptura entre os tempos sociais do tra-

\footnotetext{
32 Trata-se do patamar tecnológico industrial fossilista dos atuais padrões de produção e consumo. Este se caracteriza pelo uso de fontes de energia cada vez mais potentes, ainda predominantemente fósseis; consumo em grande escala de recursos fósseis energéticos e matérias primas que levaram bilhões de anos para serem formados na superfície terrestre, subsolo e águas profundas; consumo de recursos naturais - fontes de energia, matérias primas e intermediárias - em quantidades inéditas (a exemplo do amianto, do benzeno); geração de milhares de substâncias sintéticas novas, a cada ano; geração de resíduos tóxicos, em qualidade e quantidades inéditas; imensa capacidade de produção e destruição em massa. Para maiores detalhes, ver Altvater (1995) e Franco (2003).

${ }^{33}$ Ver Rattner (2005), Rigotto (2008), Franco (2003), dentre outros.

${ }^{34}$ Ver Capra (1982); Castleman (1996); Kurz (1997, 1999); Thébaud-Mony (1990, 2007); Torres (1993); Franco (1993, 1997, 2003); Freitas (1996); Franco; Druck (1998); Freitas, Porto; Machado (2000); Porto (2000); De Marchi; Funtowicz; Ravetz (2000); Jobin (2006); Rigotto (2008), dentre outros.
} 
balho/vida e os biorritmos humanos, nas incompatibilidades entre os tempos/ritmos do capital e os tempos da natureza, de seus ciclos e mecanismos reguladores. ${ }^{35}$

A flexibilização do trabalho acelera os tempos sociais, radicalizando este processo de inversão. Tanto o despertencimento social, quanto o desenraizamento em relação à natureza revelam o atributo inerente do capitalismo de ser um padrão civilizatório incapaz de incorporar os limites humanos e da natureza. É um tipo de sociedade que alimenta forças destrutivas da vida e não o contrário, na medida em que sua perspectiva é a dominação, o controle e a apropriação. Tocamos aqui nas raízes e nos fundamentos de uma sociedade patogênica cujos tempos sociais são incompatíveis com os tempos da natureza, ou seja, com os ciclos de autorregulação dos ecossistemas e os biorritmos humanos (tempos de autorregulação biopsíquica).

É possível e necessário mudar o padrão dominante de sociabilidade fundado na competição e divisar um mundo pautado na razão social do trabalho, transitando para sociedades com horizontes dignos para seres humanos imersos não apenas em processos sociais/culturais, mas em ciclos da natureza como todos os demais seres vivos. Seres integrantes de uma rede que precisa ser resgatada no imaginário e nas práticas sociais no sentido de preservar e defender a vida em todas as suas formas, diversidade e manifestações. Esta construção requer um novo padrão civilizatório, com diferentes padrões de produção e consumo, baseados em outras fontes de energia.

\section{À guisa de esperança: práticas de en- frentamento da precarização social}

Práticas de enfrentamento da precarização social do trabalho são louváveis, precisam ser fortalecidas e são uma necessidade em defesa da vida. Têm sido exercidas por agentes sociais diversos, tais como sindicatos de trabalhadores, o Estado - MPT, TRT, Cerest, SRTE, Fundacentro, ${ }^{36}$ universidades (instâncias que não são monolíticas, diga-se de passagem).

Nesse sentido, vale pontuar que a precarização do trabalho é uma construção histórica, sendo, portanto, modificável. Os adoecimentos e acidentes de trabalho também são evitáveis. A prevenção, embora envolva diversos níveis de complexidade, aponta para a necessidade de "civilizar" o mundo do trabalho a partir de elementos básicos, que precisam ser traduzidos em políticas públicas.
Elementos como a legislação do trabalho vigente, que está sob ameaça, precisam ser preservados e cumpridos. Direitos sociais que defendam a vida são inegociáveis. É necessário resgatar a dignidade no trabalho e sua função social, impedindo a terceirização - ilícita, ilegal e antissocial - através das cooperativas fraudulentas, o assalariamento disfarçado em prestação de serviços regulares, com pessoalidade e subordinação ao contratante, as empresas do "eu sozinho", dentre outras.

As perspectivas de solidariedade entre desempregados, terceirizados e todos aqueles que vivem do trabalho precisam ser resgatadas - reduzindo as barreiras entre sujeitos coletivos que atuam em defesa dos direitos sociais - para afirmar uma razão social do trabalho. ${ }^{37}$ Estas perspectivas passam pela necessidade de se reduzir jornadas de trabalho, sem prejuízo do salário para começarmos a trilhar dois caminhos na reconstrução do tecido social: a) desnaturalizar o recurso antissocial à hora extra e/ou às jornadas de trabalho prolongadas que levam ao adoecimento, respeitando biorritmos; b) enfrentar o empobrecimento e o desemprego - forma extrema de precarização, de negação social do indivíduo, forte geradora de adoecimento mental.

É necessário enfrentar a precarização do mundo do trabalho com expansão do emprego, favorecendo real inclusão e pertencimento social (e não apenas vias compensatórias). A redução da jornada de trabalho pode favorecer esta inclusão, sendo, na verdade, um poderoso instrumento para a geração de emprego e para as políticas de saúde pública.

Enfrentar a precarização social requer, também, mudanças de mentalidade e cultura política no sentido de civilizar os ambientes de trabalho, banindo agentes agressivos, tais como amianto, benzeno, dentre outros, para "criar um ambiente cada vez mais livre de poluentes que comprometem a existência do planeta" (SEMINÁRIO INTERNACIONAL PELO BANIMENTO DO AMIANTO, 2009, sem paginação). ${ }^{38}$ Requer desenvolver consciência em curto, médio e longo prazos voltada para diferentes padrões de produção e consumo, novas bases energéticas, vislumbrando um novo padrão de civilização que passa pela ressignificação do trabalho. Enfim, um mundo do trabalho não predatório que sirva para construir a sociabilidade e não a destruir. Que, ao nutrir-se da natureza, respeite seus ciclos, limites e complexidade.

\footnotetext{
${ }^{35}$ Este desenraizamento tem sua expressão máxima no trabalho infantil das sociedades contemporâneas que é a negação do ciclo natural da vida: criança é um ser em formação neurobiopsicossocial cuja duração e dependência é superior ao tempo de qualquer outra espécie viva conhecida neste planeta. Atropelar este processo é antinatural, indigno e antiético.

${ }^{36}$ Ministério Público do Trabalho (MPT), Tribunal Regional do Trabalho (TRT), Centro de Referência em Saúde do Trabalhador (Cerest), Superintendência Regional do Trabalho e Emprego (SRTE), Fundação Jorge Duprat Figueiredo de Segurança e Medicina do Trabalho (Fundacentro).

${ }^{37}$ No cotidiano das práticas de Saúde Pública e das atividades clínicas, cabem também desafios de retorno ao humanismo e à ética, superando as tendências burocratizantes e esterilizantes atualmente em moda e, às vezes, realizadas sob exaltação aos choques de gestão realizados em nome da excelência. Que essas atividades sejam realizadas, sim, em nome da cidadania social que se encontra em retrocesso no mundo (CASTEL, 2009) e sofre, também, pressões desestabilizadoras no Brasil (CARVALHO, 2004; IVO, 2008).

${ }^{38}$ Esta perspectiva consiste em um dos objetivos do seminário, que foi realizado pelo Sindicato Unificado dos Trabalhadores Petroleiros, Petroquímicos, Químicos e Plásticos de Alagoas e Sergipe (Sindipetro AL/SE) em 06 de novembro de 2009, em Maceió-Alagoas.
} 


\section{Contribuições de autoria}

Todas as autoras participaram da estruturação, da redação, da revisão crítica do artigo e aprovaram a versão final a ser publicada.

\section{Referências}

ALTVATER, E. O preço da riqueza. São Paulo: Editora da Universidade Estadual Paulista, 1995.

ANTUNES, R. Os sentidos do trabalho. São Paulo: Boitempo, 1999.

. As novas formas de acumulação do capital e as formas contemporâneas de estranhamento (alienação). Caderno CRH, Salvador, v. 15, n. 37, p. 23-46, 2002.

ANTUNES, R.; BRAGA, R. Infoproletários: degradação real do trabalho virtual. São Paulo: Boitempo, 2009.

APPAY, B. La dictature du succès. Paris: L'Harmattan, 2005.

APPAY, B.; THÉBAUD-MONY, A. Précarisation sociale, travail et santé. Paris: IRESCO, 1997.

ARAÚJO, A. J. S. Paradoxos da modernização: terceirização e segurança dos trabalhadores em uma refinaria de petróleo. 2001. 370 f. Tese (Doutorado)Fiocruz, Rio de Janeiro, 2001.

ARAÚJO, A.; PORTO, M. F. S. Trabalho e vida na periferia do capitalismo: terceirizados na indústria de refino de petróleo. In: ARAÚJO, A. et al. (Org.). Cenários do trabalho. Rio de Janeiro: DP\&A, 2004. p. 179-212.

AUBERT, N.; GAULEJAC, V. Le coût de l'excellence. Paris: Seuil, 1991.

BADURA, B. et al. Fehlzeiten-Report 2009 - Arbeit und Psyche. Zahlen, Daten Analysen aus allen Branchen der Wirtschaft. Heidelberg: Springer-Verlag, 2009.

BENOIT-GUILBOT, O.; GALLIE, D. Chômeurs de longue durée. Arles: Actes-Sud, 1992.

BERNARDO, M. H. Trabalho duro, discurso flexível: uma análise das contradições do toyotismo a partir da vivência de trabalhadores. São Paulo: Expressão Popular, 2009.

BOLTANSKI, L. Rendre la réalité inacceptable: à propos de la production de l'ideologie dominante. Paris: Demopolis, 2008.

BOURDIEU, P. (Org.). A miséria do mundo. 2. ed. Petrópolis: Vozes, 1997.

. Contrafogos: táticas para enfrentar a invasão neoliberal. Rio de Janeiro: Jorge Zahar, 1998.

Contrafogos 2: por um movimento social europeu. Rio de Janeiro: Jorge Zahar, 2001.

BRASIL. Ministério da Saúde. Doenças relacionadas ao trabalho: manual de procedimentos médicos.
Brasília, DF, 2001. (Série A, Manuais e normas técnicas, n. 114).

. Ministério do Trabalho e Emprego. Relatórios específicos de fiscalização para erradicação do trabalho escravo. 2009. Disponível em: <http://www. mte.gov.br>. Acesso em: dez. 2009.

BURAWOY, M. Global etnography: forces, conections and imaginations in a postmodern world. Berkeley: University of California Press, 2000.

CAMARGO, D.; CAETANO, D.; GUIMARÃES, L. Psiquiatria ocupacional II: síndromes psiquiátricas orgânicas relacionadas ao trabalho. Jornal Brasileiro de Psiquiatria, v. 54, n. 1, p. 21-33, 2005.

CAPRA, F. O ponto de mutação. São Paulo: Cultrix, 1982.

CARDOSO, A. M. A década neoliberal e a crise dos sindicatos no Brasil. São Paulo: Boitempo, 2003.

CARELLI, R. L. Cooperativa de mão-de-obra: manual contra a fraude. São Paulo: LTr, 2002.

. Terceirização e intermediação de mão-deobra: ruptura do sistema trabalhista, precarização do trabalho e exclusão social. Rio de Janeiro: Renovar, 2003.

CARVALHO, J. M. Cidadania no Brasil. Rio de Janeiro: Civilização Brasileira, 2004.

CASTEL, R. As metamorfoses da questão social: uma crônica do salário. Rio de Janeiro: Vozes, 1998.

. La montée des incertitudes: travail, protections, statut de l'individu. Paris: Seuil, 2009.

CASTLEMAN, B. A migração de riscos industriais. Caderno CRH, Salvador, v. 9, n. 24/25, p. 41-67, 1996.

CEPAL; PNUD; OIT. Emprego, desenvolvimento humano e trabalho decente: a experiência brasileira recente. Brasília, DF, 2008.

CHESNAIS, F. A mundialização do capital. São Paulo: Xamã, 1996.

CLOT, Y. Travail et pouvoir d'agir. Paris: PUF, 2008.

COSTA, F. B. Garis: um estudo de psicologia sobre invisibilidade pública. 2002. 177 f. Dissertação (Mestrado)-Instituto de Psicologia, Universidade de São Paulo, São Paulo, 2002.

DAHLBERG, L. L.; KRUG, E. G. Violência como problema global de saúde pública. Ciência e Saúde Coletiva, v. 11, n. 2, p. 277-292, 2006. 
DAVEZIES, P. Les impasses du harcèlement moral. Travailler, Paris, v. 1, n. 11, p. 83-90, 2004.

DEJOURS, C. A banalização da injustiça social. Rio de Janeiro: Fundação Getúlio Vargas, 1999.

. Activisme professionnel: masochisme, compulsivité ou alienation? Travailler, Paris, v. 1, n. 11, p. 25-40, 2004.

. Conjurer la violence-travail, violence et santé. Paris: Payot, 2007.

DEJOURS, C.; BÈGUE, F. Suicide et travail: que faire ? Paris: PUF, 2009.

DE MARCHI, B.; FUNTOWICZ, S.; RAVETZ, J. O acidente industrial ampliado de Seveso: paradigma e paradoxo. In: FREITAS, C. M.; PORTO, M. F. S; MACHADO, J. M. H. (Org.). Acidentes industriais ampliados: desafios e perspectivas para o controle e a prevenção. Rio de Janeiro: Fiocruz, 2000. p. 129-148.

DEPARTAMENTO INTERSINDICAL DE ESTATÍSTICA E ESTUDOS SOCIOECONÔMICOS. PED - Pesquisa de Emprego e Desemprego no período de 1990-2008. Disponível em: <www.dieese.org.br/ped/ped.xml>. Acesso em: 17 jun. 2010.

DONIOL-SHAW, G.; HUEZ, D.; SANDRET, N. Les maux de la sous-traitance. Toulouse: Octares, 2001.

DORAY, B. Le taylorisme, une folie rationnelle? Paris: Dunod, 1981.

La dignité. Paris: La Dispute, 2006.

DRUCK, G. Terceirização: (des)fordizando a fábrica - um estudo do complexo petroquímico. São Paulo: Boitempo, 1999.

DRUCK, G.; FRANCO, T. A perda da razão social do trabalho: terceirização e precarização. São Paulo: Boitempo, 2007.

ELKELES, T.; SEIFERT, W. Arbeitslose und ihere Gesundheit. Berlin: Wissenchaftszentrum Berlin für Sozialforschung, 1992.

FISCHER, F. M.; LIEBER, R. R. Trabalho em turnos. In: MENDES, R. Patologias do trabalho. 2. ed. Rio de Janeiro: Atheneu, 2003. p. 825-868.

FLOEN, S. K.; ELKIT, A. Psychiatric diagnoses, trauma and suicidiality. Annals of General Psychiatry, v. 6, n. 12. Disponível em: <http://www.pubmedcentral.nih. gov/articlerender.fcgi? artid $=1858696>$. Acesso em: 12 abr. 2009.

FRANCO, T. Trabalho industrial e meio ambiente: a experiência do complexo industrial de Camaçari. In: MARTINE, G. (Org.). População, meio ambiente e desenvolvimento: verdades e contradições. Campinas: Unicamp, 1993. p. 60-100.

Trabalho, riscos industriais e meio ambiente: rumo ao desenvolvimento sustentável?. Salvador: EdUFBa, 1997.

Trabalho alienado: habitus \& danos à saúde humana e ambientais. (O trabalho entre o céu, a terra e a história). 2003. 254 f. Tese (Doutorado)-Faculdade de
Filosofia e Ciências Humanas, Universidade Federal da Bahia, Salvador, 2003.

FRANCO, T.; DRUCK, G. Padrões de industrialização, riscos e meio ambiente. Ciência e Saúde Coletiva, Rio de Janeiro, v. 3, n. 2, p. 61-71, 1998.

FREITAS, C. M. Acidentes químicos ampliados: incorporando a dimensão social nas análises de riscos. 1996. 243 f. Tese (Doutorado)-Escola Nacional de Saúde Pública/Fundação Oswaldo Cruz, Rio de Janeiro. Rio de Janeiro: fiocruz, 1996.

FREITAS, C. M.; PORTO, M. F. S.; MACHADO, J. M. H. (Org.). Acidentes industriais ampliados: desafios e perspectivas para o controle e a prevenção. Rio de Janeiro: Fiocruz, 2000.

FREITAS, M. E.; HELOANI, E.; BARRETO, M. Assédio moral no trabalho. São Paulo: Cengage Learning, 2008.

FREUDENBERGER, H. J. L'épuisement professionnel: "la brûlure interne”. Quebec: Gaetan Morin, 1987.

GIMENEZ, D. M. et al. As cooperativas de mão-de-obra e os tribunais regionais do trabalho, 2003. Disponível em < http://www.saudeetrabalho.com.br>. Acesso em: 1 jun. 2006.

GREY, C. O fetiche da mudança. Revista de Administração de Empresas (RAE), v. 44, n. 1, p. 9-25, 2004.

GUIMARÃES, N. A. Caminhos cruzados: estratégias de empresas e trajetórias de trabalhadores. São Paulo: Editora 34, 2004.

HALLQVIST, J.; et al. Is the effect of job strain on miocardial infarction risk due to interaction between high psychological demands and low decision latitude? Results from Stockholm Heart Epidemiology Program (SHEEP). Social Science \& Medicine, v. 46, n. 11, p. 1405-1415, 1998.

HARVEY, D. Condição pós-moderna. São Paulo: Loyola, 1992.

HELOANI, R. Gestão e organização no capitalismo globalizado. São Paulo: Atlas, 2003.

HIRATA, H.; HUMPHREY, J. Trabalhadores desempregados: trajetórias de operárias e operários industriais no Brasil. Revista Brasileira de Ciências Sociais, v. 4, n. 11, p. 71-84, out. 1989.

HIRATA, H.; PRETÉCEILLE, E. Trabalho, exclusão e precarização socioeconômica: o debate das ciências sociais na França. Caderno CRH, Salvador, v. 15, n. 37, p. 47-80, 2002.

HIRIGOYEN, M. F. Le harcèlement moral: la violence perverse au quotidien. Paris: La Découverte, 1998. Obra traduzida e publicada no Brasil como HIRIGOYEN, M. F. Assédio moral: a violência perversa no cotidiano. Tradução Maria Helena Kühner. Rio de Janeiro: Bertrand Brasil, 2001.

. Mal-estar no trabalho. Rio de Janeiro: Bertrand Brasil, 2002. 
HOBSBAWM, E. J. A era dos extremos: o breve século XX (1914-1991). 2. ed. São Paulo: Companhia das Letras, 1995.

HUWS, U. Women's health at work. In: The making of a cybertariat. Londres: Merlin Press, 2003. p. 77-85.

INSTITUTO BRASILEIRO DE GEOGRAFIA E ESTATÍSTICA. PME (Pesquisa Mensal de Emprego) no período de out. 2008 a nov. 2009. Rio de Janeiro, 2009a.

. PNAD (Pesquisa Nacional por Amostra de Domicílio) no período de 1992-2008. Rio de Janeiro, 2009b.

INTERNATIONAL LABOUR ORGANIZATION. World of work report 2009: the global jobs crisis and beyond. Geneva, 2009.

INTERNATIONAL LABOUR ORGANIZATION. International Institute for Labour Studies. World of work report 2008: income inequalities in the age of financial globalization. Geneva, 2008.

IVO, A. B. L. Viver por um fio: pobreza e política social. São Paulo: Anablume; Salvador: CRH/UFBA, 2008. $258 \mathrm{p}$.

JAHODA, M.; LAZARSFELD, P.; ZEISEL, H. Die Arbeitslosen von Marienthal (1933). Frankfurt/Main: Suhrkamp, 1975.

JOBIN, P. Maladies industrialles et renoveau syndical au Jaon. París: Éditions de l'École des Hautes Études en Sciences Sociales, 2006.

KNAPP, T. Burn-out; Le stress au travail. La maladie du XXI siècle. Sainte-Croix: Les Presses du Belvédère, 2006.

KREIN, J. D. Balanço da reforma trabalhista no governo FHC. In: PRONI, M. W.; HENRIQUE, W. (Org.). Trabalho, mercado e sociedade. São Paulo: Unesp/Inst. Economia Unicamp, 2003. p. 279-322.

. As tendências recentes nas relações de emprego no Brasil: 1990-2005. 2007. 329 f. Tese (Doutorado em Economia Social e do Trabalho)-Universidade Estadual de Campinas, Campinas, SP, 2007.

KURZ, R. Os últimos combates. Petrópolis, RJ: Vozes, 1997.

. O colapso da modernização. 5. ed. rev. São Paulo: Paz e Terra, 1999.

LAVINAS, L. et al. Trabalho a domicílio: novas formas de contratação. Genebra: OIT, 1998.

LE BLANC, G. Vies ordinaries, vies précaires. Paris: Seuil, 2007.

. L’invisibilité sociale. Paris: PUF, 2009.

LHUILIER, D. Cliniques du travail. Paris: Érès, 2007.

LIMA, J. C. O trabalho autogestionário em cooperativas de produção: o paradigma revisitado. Revista Brasileira de Ciências Sociais, v. 19, n. 56, p. 45-62, 2004.
. O trabalho em cooperativas: dilemas e perspectivas. In: DRUCK, G.; FRANCO, T. A perda da razão social do trabalho: terceirização e precarização. São Paulo: Boitempo, 2007. p. 69-80.

LIMA, J. C.; SOARES, M. J. Trabalho flexível e o novo informal. Caderno CRH, Salvador, v. 15, n. 37, p. 163180, jul./dez. 2002.

LIMA, M. E. A. Os equívocos da excelência. Petrópolis: Vozes, 1996.

LINHART, D. Salariés du privé: une «éthique du dévouement» exigée au nom de l'entreprise. Problèmes Politiques et Sociaux au Travail, n. 965, p. 32-34, 2009.

MAENO, M. Reinserção de trabalhadores com lesões por esforços repetitivos no mercado de trabalho. 2001. 117 f. Dissertação (Mestrado)-Faculdade de Saúde Pública, Universidade de São Paulo, São Paulo, 2001.

MARZANO, M. Travail compulsif et effacement de la subjectivité: l'hyperactivité comme fuite. Travailler, Paris, v. 1, n. 11, p. 7-24, 2004. Dossier L’Hyperactivité.

MERLO, A. R. C.; MENDES, A. M. B. Perspectivas do uso da psicodinâmica do trabalho no Brasil: teoria, pesquisa e ação. Cadernos de Psicologia Social do Trabalho, v. 12, n. 2, p. 141-156, 2009.

MONROY, M. La violence de l'excellence. Revigny-surOrnam: Martin Media, 2000.

NARDI, H. C. Ética, trabalho e subjetividade: trajetórias de vida no contexto das transformações do capitalismo contemporâneo. Porto Alegre: UFRGS, 2006.

NATIONAL DEFENSE COUNSEL FOR VICTIMS OF KAROSHI. Karoshi: when the "Corporate Warrior" dies. Tokyo: Mado-Sha, 1990.

ORGANIZAÇÃO INTERNACIONAL DO TRABALHO. Trabalho decente nas Américas: uma agenda hemisférica 2006-2015. In: REUNIÃO REGIONAL AMERICANA,16., 2006. Anais... Brasília, DF, 2006. DF, 2009.

Perfil do trabalho decente no Brasil. Brasília,

PAPARELLI, R. Desgaste mental do professor da rede pública de ensino: trabalho sem sentido sob a política de regularização do fluxo escolar. 2009. 184 f. Tese (Doutorado em Psicologia Social e do Trabalho)Instituto de Psicologia, Universidade de São Paulo, São Paulo, 2009.

PASSET, R. A ilusão neoliberal. Rio de Janeiro: Record, 2002.

PEZÉ, M. Ils ne mouraient pas tous mais tous étaient frapés. Paris: Pearson, 2008.

. Du stress au «Karoshi»: les victimes de mort subite au travail. Problèmes politiques et sociaux au travail. La Documentation Française, n. 965, p. 67-70, 2009. 
PICCININI, V. C. Cooperativas de trabalho de Porto Alegre e flexibilização do trabalho, Sociologias, n. 12, p. 68-105, 2004.

PORTO, M. F. de S. Considerações sobre a dinâmica de regulação dos riscos industriais e a vulnerabilidade da sociedade brasileira. In: HERCULANO, S.; PORTO, M. F. de S.; FREITAS, C. M. (Org.). Qualidade de vida e riscos ambientais. Niterói: UFF, 2000. p. 147-170.

RATTNER, H. O resgate da utopia: cultura, política e sociedade. São Paulo: Palas Athena, 2005.

RIGOTTO, R. M. Desenvolvimento, ambiente e saúde: implicações da (des)localização industrial. Rio de Janeiro: Fiocruz, 2008.

SAINSAULIEU, R. L'identité au travail. Paris: Presses de la Fondation Nationale des Sciences Politiques, 1988.

SANTOS, M. A. F. Patologia da solidão: o suicídio de bancários no contexto da nova organização do trabalho. 2009. 223 f. Dissertação (Mestrado em Administração)-Universidade de Brasília, Brasília, DF, 2009.

SATO, L. Abordagem do trabalho penoso: estudo de caso de motoristas de ônibus urbanos. 1991. $119 \mathrm{f}$. Dissertação (Mestrado em Psicologia)-Faculdade de Psicologia, Pontifícia Universidade Católica de São Paulo, São Paulo, 1991.

SELIGMANN-SILVA, E. Desgaste mental no trabalho dominado. São Paulo: Cortez, 1994.

. A interface desemprego prolongado e saúde psicossocial. In: SILVA FILHO, J. F.; JARDIM, S. (Org.). A danação do trabalho. Rio de Janeiro: Te Corá, 1997. p. 19-63.

. Desemprego e psicopatologia da recessão. In: BORGES, L. H.; MOULIN, M. G. B.; ARAÚJO, M. D. (Org.). Organização do trabalho e saúde: múltiplas relações. Vitória: UFES, 2001. p. 219-254.

. Psicopatologia e saúde mental no trabalho. In: MENDES, R. (Org.). Patologia do trabalho. Rio de Janeiro: Atheneu, 2003. p. 1142-1182.

. Os riscos da insensibilidade. In: ARAÚJO, A. et al. (Org.). Cenários do trabalho. Rio de Janeiro: DP\&A, 2004. p. 51-72.

. Desgaste mental no trabalho dominado. 2. ed. rev. e aum. São Paulo: Cortez, [2011]. No prelo.
SEMINÁRIO INTERNACIONAL PELO BANIMENTO DO AMIANTO, 1., 2009, Maceió. Documento de divulgação. Maceió: Sindipetro AL/SE, 2009.

SENNETT, R. A corrosão do caráter: conseqüências pessoais do trabalho no novo capitalismo. São Paulo: Record, 1999.

. A cultura do novo capitalismo. Rio de Janeiro: $\overline{\text { Record, }} 2006$.

SILVA, S.; FRANCO, T. Flexibilização do trabalho: vulnerabilidade da prevenção e fragilização sindical. In: DRUCK, G.; FRANCO, T. A perda da razão social do trabalho: terceirização e precarização. São Paulo: Boitempo, 2007. p. 119-146.

SILVEIRA, A. A participação dos trabalhadores na redução e eliminação da nocividade do trabalho. In: MENDES, R. (Org.). Patologias do trabalho. Rio de Janeiro: Atheneu, 2003. v. 2, p. 1817-1833.

SOBOLL, L. A. Assédio moral no Brasil: a ampliação conceitual e suas repercussões. In: SOBOLL, L. A. (Org.). Violência psicológica e assédio moral no trabalho. São Paulo: Casa do Psicólogo, 2008. p. 23-55. SPINOZA, B. Ética. Belo Horizonte: Autêntica, 2007. THÉBAUD-MONY, A. L'envers des sociétés industrielles: approche comparative franco-brésiliènne. Paris: L’Harmatan, 1990.

. Travailler peut nuire gravement à votre santé. Paris: La Découverte, 2007.

. Renault, EDF, PSA: effets de la pression et cas de suicides. Problèmes politiques et sociaux au travail. La Documentation Française, n. 965, p. 70-71, 2009.

THÉBAUD-MONY, A.; DRUCK, G. Terceirização: a erosão dos direitos dos trabalhadores na França e no Brasil. In: DRUCK, G.; FRANCO, T. A perda da razão social do trabalho: terceirização e precarização. São Paulo: Boitempo, 2007. p. 23-58.

TORRES, H. Indústrias sujas e intensivas em recursos: importância crescente no cenário industrial brasileiro. In: MARTINE, G. (Org.). População, meio ambiente e desenvolvimento: verdades e contradições. Campinas: Unicamp, 1993. p. 43-67.

WORLD HEALTH ORGANIZATION. The ICD-10 Classification of mental and behavioural disorders. Geneva, 1992. 